4

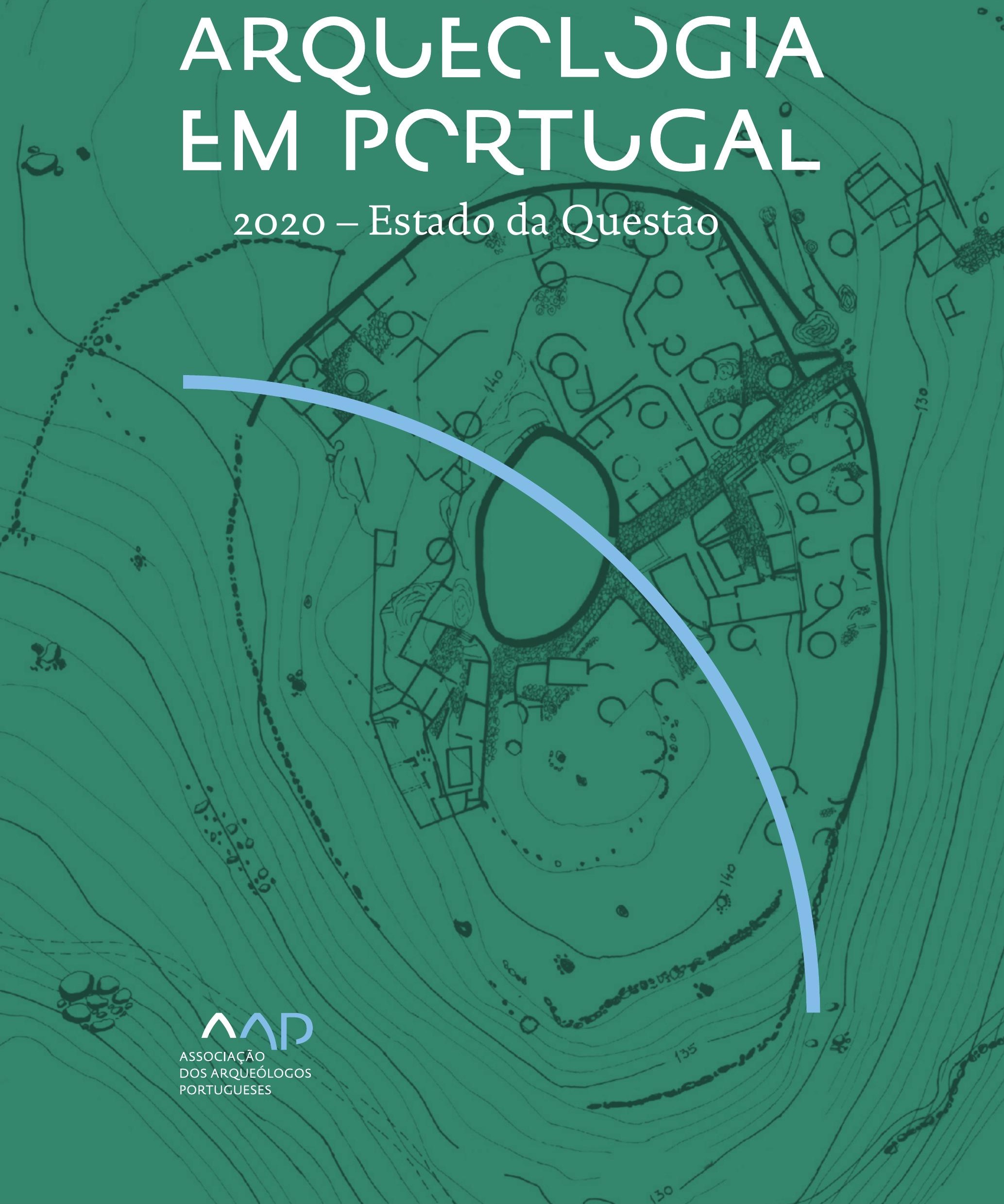


Coordenação editorial: José Morais Arnaud, César Neves e Andrea Martins Design gráfico: Flatland Design

AAP - ISBN: 978-972-9451-89-8

CITCEM - ISBN: 978-989-8970-25-1

Associação dos Arqueólogos Portugueses e CITCEM

Lisboa, 2020

O conteúdo dos artigos é da inteira responsabilidade dos autores. Sendo assim a Associação dos Arqueólogos Portugueses declina qualquer responsabilidade por eventuais equívocos ou questões de ordem ética e legal.

Desenho de capa:

Planta do castro de Monte Mozinho (Museu Municipal de Penafiel).

\section{$\hat{\wedge} \mathrm{P}$}

DOS ARQUEÓLOGOS PORTUGUESES

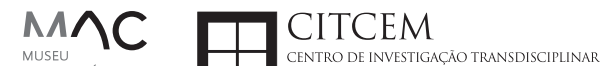
MUSEU
ARQUELLÓGICO
DO CARMO
U.PORTO

FLUP FACULDADE DE LETRAS
UNIVERSIDADE DO PORTO

Apoio

EC para a Ciência 


\section{Índice}

15 Prefácio

José Morais Arnaud

\section{Historiografia e Teoria}

17 Território, comunidade, memória e emoção: a contribuição da história da arqueologia (algumas primeiras e breves reflexões)

Ana Cristina Martins

25 Como descolonizar a arqueologia portuguesa?

Rui Gomes Coelho

41 Arqueologia e Modernidade: uma revisitação pessoal e breve de alguns aspetos da obra homónima de Julian Thomas de 2004

Vítor Oliveira Jorge

57 Dados para a História das Mulheres na Arqueologia portuguesa, dos finais do século XIX aos inícios do século XX: números, nomes e tabelas

Filipa Dimas / Mariana Diniz

73 Retractos da arqueologia portuguesa na imprensa: (in)visibilidades no feminino

Catarina Costeira / Elsa Luís

85 Arqueologia e Arqueólogos no Norte de Portugal Jacinta Bugalhão

101 Vieira Guimarães (1864-1939) e a arqueologia em Tomar: uma abordagem sobre o território e as gentes

João Amendoeira Peixoto / Ana Cristina Martins

115 Os memoráveis? A arqueologia algarvia na imprensa nacional e regional na presente centúria (2001-2019): características, visões do(s) passado(s) e a arqueologia

enquanto marca

Frederico Agosto / João Silva

129 A Evolução da Arqueologia Urbana e a Valorização Patrimonial no Barlavento Algarvio: Os casos de Portimão e Silves

Artur Mateus / Diogo Varandas / Rafael Boavida

\section{Gestão, Valorização e Salvaguarda do Património}

145 O Caderno Reivindicativo e as condições de trabalho em Arqueologia Miguel Rocha / Liliana Matias Carvalho / Regis Barbosa / Mauro Correia / Sara Simões / Jacinta Bugalhão / Sara Brito / Liliana Veríssimo Carvalho / Richard Peace / Pedro Peça / Cézer Santos

155 Os Estudos de Impacte Patrimonial como elemento para uma estratégia sustentável de minimização de impactes no âmbito de reconversões agrícolas Tiago do Pereiro

165 Salvaguarda de Património arqueológico em operações florestais: gestão e sensibilização Filipa Bragança / Gertrudes Zambujo / Sandra Lourenço / Belém Paiva / Carlos Banha / Frederico Tatá Regala / Helena Moura / Jacinta Bugalhão / João Marques / José Correia / Pedro Faria / Samuel Melro

179 Os valores do Património: uma investigação sobre os Sítios Pré-históricos de Arte Rupestre do Vale do Rio Côa e de Siega Verde José Paulo Francisco 
189 Conjugando recursos arqueológicos e naturais para potenciar as visitas ao Geoparque Litoral de Viana do Castelo (Noroeste de Portugal)

Hugo A. Sampaio / Ana M.S. Bettencourt / Susana Marinho / Ricardo Carvalhido

203 Áreas de Potencial Arqueológico na Região do Médio Tejo: Modelo Espacial Preditivo Rita Ferreira Anastácio / Ana Filipa Martins / Luiz Oosterbeek

223 Património Arqueológico e Gestão Territorial: O contributo da Arqueologia para a revisão do PDM de Avis

Ana Cristina Ribeiro

237 A coleção arqueológica do extinto Museu Municipal do Porto - Origens, Percursos e Estudos

Sónia Couto

251 Valpaços - uma nova carta arqueológica

Pedro Pereira / Maria de Fátima Casares Machado

263 Arqueologia na Cidade de Peniche

Adriano Constantino / Luís Rendeiro

273 Arqueologia Urbana: a cidade de Lagos como caso de Estudo Cátia Neto

285 Estratégias de promoção do património cultural subaquático nos Açores. O caso da ilha do Faial

José Luís Neto / José Bettencourt / Luís Borges / Pedro Parreira

297 Carta Arqueológica da Cidade Velha: Uma primeira abordagem

Jaylson Monteiro / Nireide Tavares / Sara da Veiga / Claudino Ramos / Edson Brito /

Carlos Carvalho / Francisco Moreira / Adalberto Tavares

311 Antropologia Virtual: novas metodologias para a análise morfológica e funcional Ricardo Miguel Godinho / Célia Gonçalves

\section{Didáctica da Arqueologia}

327 Como os projetos de Arqueologia podem contribuir para uma comunidade culturalmente mais consciente Alexandra Figueiredo / Claúdio Monteiro / Adolfo Silveira / Ricardo Lopes

337 Educação Patrimonial - Um cidadão esclarecido é um cidadão ativo! Ana Paula Almeida

351 A aproximação da Arqueologia à sala de aula: um caso de estudo no $3^{\circ}$ ciclo do Ensino Básico Luís Serrão Gil

363 Arqueologia 3.o - Pensar e comunicar a Arqueologia para um futuro sustentável Mónica Rolo

377 “Conversa de Arqueólogos" - Divulgar a Arqueologia em tempos de Pandemia Diogo Teixeira Dias

389 Escola Profissional de Arqueologia: desafios e oportunidades Susana Nunes / Dulcineia Pinto / Júlia Silva / Ana Mascarenhas

399 Os Museus de Arqueologia e os Jovens: a oferta educativa para o público adolescente Beatriz Correia Barata / Leonor Medeiros

411 O museu universitário como mediador entre a ciência e a sociedade: o exemplo da secção de arqueologia no Museu de História Natural e da Ciência da Universidade do Porto (MHNC-UP)

Rita Gaspar 
421 Museu de Lanifícios: Real Fábrica de Panos. Atividades no âmbito da Arqueologia Beatriz Correia Barata / Rita Salvado

427 Arqueologia Pública e o caso da localidade da Mata (Torres Novas) Cláudia Manso / Ana Rita Ferreira / Cristiana Ferreira / Vanessa Cardoso Antunes

431 Do sítio arqueológico ao museu: um percurso (também) didático Lídia Fernandes

447 Estão todos convidados para a Festa! E para dançar também... O projecto do Serviço Educativo do Museu Arqueológico do Carmo na $5^{\underline{a}}$ Edição da Festa da Arqueologia Rita Pires dos Santos

459 O “Clã de Carenque”, um projeto didático de arqueologia Eduardo Gonzalez Rocha

469 Mediação cultural: peixe que puxa carroça nas Ruínas Romanas de Troia Inês Vaz Pinto / Ana Patrícia Magalhães / Patrícia Brum / Filipa Santos

481 Didática Arqueológica, experiências do Projeto Mértola Vila Museu Maria de Fátima Palma / Clara Rodrigues / Susana Gómez / Lígia Rafael

\section{Arte Rupestre}

497 Os inventários de arte rupestre em Portugal Mila Simões de Abreu

513 O projeto FIRST-ART - conservação, documentação e gestão das primeiras manifestações de arte rupestre no Sudoeste da Península Ibérica: as grutas do Escoural e Maltravieso Sara Garcês / Hipólito Collado / José Julio García Arranz / Luiz Oosterbeek / António Carlos Silva / Pierluigi Rosina / Hugo Gomes / Anabela Borralheiro Pereira / George Nash / Esmeralda Gomes / Nelson Almeida / Carlos Carpetudo

523 Trabalhos de documentação de arte paleolítica realizados no âmbito do projeto PalæoCôa André Tomás Santos / António Fernando Barbosa / Luís Luís / Marcelo Silvestre / Thierry Aubry

537 Imagens fantasmagóricas, silhuetas elusivas: as figuras humanas na arte do Paleolítico Superior da região do Côa Mário Reis

$55^{1}$ Os motivos zoomórficos representados nas placas de tear de Vila Nova de São Pedro (Azambuja, Portugal) Andrea Martins / César Neves / José M. Arnaud / Mariana Diniz

571 Arte Rupestre do Monte de Góios (Lanhelas, Caminha). Síntese dos resultados dos trabalhos efectuados em 2007-2009 Mário Varela Gomes

599 Gravuras rupestres de barquiformes no Monte de S. Romão, Guimarães, Noroeste de Portugal Daniela Cardoso

613 Círculos segmentados gravados na Bacia do Rio Lima (Noroeste de Portugal): contributos para o seu estudo Diogo Marinho / Ana M.S. Bettencourt / Hugo Aluai Sampaio

631 Equídeos gravados no curso inferior do Rio Mouro, Monção (NW Portugal). Análise preliminar Coutinho, L.M. / Bettencourt, A.M.S / Sampaio, Hugo A.S

645 Paletas na Arte Rupestre do Noroeste de Portugal. Inventário preliminar Bruna Sousa Afonso / Ana M. S. Bettencourt / Hugo A. Sampaio 


\section{Pré-História}

661 O projeto Miño/Minho: balanço de quatro anos de trabalhos arqueológicos Sérgio Monteiro-Rodrigues / João Pedro Cunha-Ribeiro / Eduardo Méndez-Quintas / Carlos Ferreira / Pedro Xavier / José Meireles / Alberto Gomes / Manuel Santonja / Alfredo Pérez-González

677 A ocupação paleolítica da margem esquerda do Baixo Minho: a indústria lítica do sítio de Pedreiras 2 (Monção, Portugal) e a sua integração no contexto regional Carlos Ferreira / João Pedro Cunha-Ribeiro / Sérgio Monteiro-Rodrigues / Eduardo Méndez-Quintas / Pedro Xavier / José Meireles / Alberto Gomes / Manuel Santonja / Alfredo Pérez-González

693 O sítio acheulense do Plistocénico médio da Gruta da Aroeira Joan Daura / Montserrat Sanz / Filipa Rodrigues / Pedro Souto / João Zilhão

703 As sociedades neandertais no Barlavento algarvio: modelos preditivos com recurso aos SIG

Daniela Maio

715 A utilização de quartzo durante o Paleolítico Superior no território dos vales dos rios Vouga e Côa

Cristina Gameiro / Thierry Aubry / Bárbara Costa / Sérgio Gomes / Luís Luís / Carmen Manzano / André Tomás Santos

733 Uma perspetiva diacrónica da ocupação do concheiro do Cabeço da Amoreira (Muge, Portugal) a partir da tecnologia lítica Joana Belmiro / João Cascalheira / Célia Gonçalves

745 Novos dados sobre a Pré-história Antiga no concelho de Palmela. A intervenção arqueológica no sítio do Poceirão I

Michelle Teixeira Santos

757 Problemas em torno de Datas Absolutas Pré-Históricas no Norte do Alentejo Jorge de Oliveira

771 Povoamento pré-histórico nas áreas montanhosas do NO de Portugal: o Abrigo 1 de Vale de Cerdeira Pedro Xavier / José Meireles / Carlos Alves

783 Apreciação do povoamento do Neolítico Inicial na Baixa Bacia do Douro. A Lavra I (Serra da Aboboreira) como caso de estudo Maria de Jesus Sanches

797 O Processo de Neolitização na Plataforma do Mondego: os dados do Sector C do Outeiro dos Castelos de Beijós (Carregal do Sal)

João Carlos de Senna-Martinez / José Manuel Quintã Ventura / Andreia Carvalho / Cíntia Maurício

823 Novos trabalhos na Lapa da Bugalheira (Almonda, Torres Novas) Filipa Rodrigues / Pedro Souto / Artur Ferreira / Alexandre Varanda / Luís Gomes / Helena Gomes / João Zilhão

837 A pedra polida e afeiçoada do sítio do Neolítico médio da Moita do Ourives (Benavente, Portugal)

César Neves

857 Casal do Outeiro (Encarnação, Mafra): novos contributos para o conhecimento do povoamento do Neolítico final na Península de Lisboa.

Cátia Delicado / Carlos Maneira e Costa / Marta Miranda / Ana Catarina Sousa

873 Stresse infantil, morbilidade e mortalidade no sítio arqueológico do Neolítico Final/ Calcolítico ( $4^{\circ}$ e $3^{\circ}$ milénio a.C.) do Monte do Carrascal 2 (Ferreira do Alentejo, Beja) Liliana Matias de Carvalho / Sofia N. Wasterlain 
885 Come together: O Conjunto Megalítico das Motas (Monção, Viana do Castelo) e as expressões Campaniformes do Alto Minho Ana Catarina Basílio / Rui Ramos

899 Trabalhos arqueológicos no sítio Calcolítico da Pedreira do Poio Carla Magalhães / João Muralha / Mário Reis / António Batarda Fernandes

913 O sítio arqueológico de Castanheiro do Vento. Da arquitectura do sítio à arquitectura de um território João Muralha Cardoso

925 Estudo zooarqueológico das faunas do Calcolítico final de Vila Nova de São Pedro (Azambuja, Portugal): Campanhas de 2017 e 2018 Cleia Detry / Ana Catarina Francisco / Mariana Diniz / Andrea Martins / César Neves / José Morais Arnaud

943 As faunas depositadas no Museu Arqueológico do Carmo provenientes de Vila Nova de São Pedro (Azambuja): as campanhas de 1937 a 1967 Ana Catarina Francisco / Cleia Detry / César Neves / Andrea Martins / Mariana Diniz / José Morais Arnaud

959 Análise funcional de material lítico em sílex do castro de Vila Nova de S. Pedro (Azambuja, Portugal): uma primeira abordagem Rafael Lima

971 O recinto da Folha do Ouro 1 (Serpa) no contexto dos recintos de fossos calcolíticos alentejanos

António Carlos Valera / Tiago do Pereiro / Pedro Valério / António M. Monge Soares

\section{Proto-História}

987 Produção de sal marinho na Idade do Bronze do noroeste Português. Alguns dados para uma reflexão

Ana M. S. Bettencourt / Sara Luz / Nuno Oliveira / Pedro P. Simões / Maria Isabel C. Alves / Emílio Abad-Vidal

1001 A estátua-menir do Pedrão ou de São Bartolomeu do Mar (Esposende, noroeste de Portugal) no contexto arqueológico da fachada costeira de entre os rios Neiva e Cávado Ana M. S. Bettencourt / Manuel Santos-Estévez / Pedro Pimenta Simões / Luís Gonçalves

1015 O Castro do Muro (Vandoma/Baltar, Paredes) - notas para uma biografia de ocupação da Idade do Bronze à Idade Média

Maria Antónia D. Silva / Ana M. S. Bettencourt / António Manuel S. P. Silva / Natália Félix

1031 Do Bronze Final à Idade Média - continuidades e hiatos na ocupação de Povoados em Oliveira de Azeméis João Tiago Tavares / Adriaan de Man

1041 As faunas do final da Idade do Bronze no Sul de Portugal: leituras desde o Outeiro do Circo (Beja)

Nelson J. Almeida / Íris Dias / Cleia Detry / Eduardo Porfírio / Miguel Serra

1055 A Espada do Monte das Oliveiras (Serpa) - uma arma do Bronze Pleno do Sudoeste Rui M. G. Monge Soares / Pedro Valério / Mariana Nabais / António M. Monge Soares

1065 São Julião da Branca (Albergaria-a-Velha) - Investigação e valorização de um povoado do Bronze Final

António Manuel S. P. Silva / Paulo A. P. Lemos / Sara Almeida e Silva / Edite Martins de Sá

1083 Do castro de S. João ao Mosteiro de Santa Clara: notícia de uma intervenção arqueológica, em Vila do Conde Rui Pinheiro 
1095 O castro de Ovil (Espinho), um quarto de século de investigação - resultados e questões em aberto

Jorge Fernando Salvador / António Manuel S. P. Silva

1111 O Castro de Salreu (Estarreja), um povoado proto-histórico no litoral do Entre Douro e Vouga

Sara Almeida e Silva / António Manuel S. P. Silva / Paulo A. P. Lemos / Edite Martins de Sá

1127 Castro de Nossa Senhora das Necessidades (Sernancelhe): uma primeira análise artefactual Telma Susana O. Ribeiro

${ }_{1141}$ A cividade de Bagunte. O estado atual da investigação Pedro Brochado de Almeida

1153 Zoomorfos na cerâmica da Idade do Ferro no NW Peninsular: inventário, cronologias e significado Nuno Oliveira / Cristina Seoane

1163 Vasos gregos em Portugal: diferentes maneiras de contar a história do intercâmbio cultural na Idade do Ferro

Daniela Ferreira

1175 Os exotica da necrópole da Idade do Ferro do Olival do Senhor dos Mártires (Alcácer do Sal) no seu contexto regional

Francisco B. Gomes

\section{Antiguidade Clássica e Tardia}

1191 O uso de madeira como combustível no sítio da Quinta de Crestelos (Baixo Sabor): da Idade do Ferro à Romanização Filipe Vaz / João Tereso / Sérgio Simões Pereira / José Sastre / Javier Larrazabal Galarza / Susana Cosme / José António Pereira / Israel Espi

1207 Cultivos de Época Romana no Baixo Sabor: continuidade em tempos de mudança? João Pedro Tereso / Sérgio Simões Pereira / Filipe Santos / Luís Seabra / Filipe Vaz

1221 A casa romana na Hispânia: aplicação dos modelos itálicos nas províncias ibéricas Fernanda Magalhães / Diego Machado / Manuela Martins

1235 As pinturas murais romanas da Rua General Sousa Machado, n. ${ }^{5}$ 1, Chaves José Carvalho

1243 Trás do Castelo (Vale de Mir, Pegarinhos, Alijó) - Uma exploração agrícola romana do Douro

Tony Silvino / Pedro Pereira

1255 A sequência de ocupação no quadrante sudeste de Bracara Augusta: as transformações de uma unidade doméstica Lara Fernandes / Manuela Martins

1263 Os Mosaicos com decoração geométrica e geométrico-vegetalista dos sítios arqueológicos da área do Conuentus Bracaraugustanus. Novas abordagens quanto à conservação, restauro, decoração e datação Maria de Fátima Abraços / Licínia Wrench

1277 “Casa Romana” do Castro de São Domingos (Cristelos, Lousada): Escavação, Estudo e Musealização Paulo André de P. Lemos

1291 A arqueobotânica no Castro de Guifões (Matosinhos, Noroeste de Portugal): O primeiro estudo carpológico

Luís Seabra / Andreia Arezes / Catarina Magalhães / José Varela / João Pedro Tereso 
1305 Um Horreum Augustano na Foz do Douro (Monte do Castelo de Gaia, Vila Nova de Gaia) Rui Ramos

1311 Ponderais romanos na Lusitânia: padrões, formas, materiais e contextos de utilização Diego Barrios Rodríguez

1323 Um almofariz centro-itálico na foz do Mondego

Marco Penajoia

1335 Estruturas romanas de Carnide - Lisboa Luísa Batalha / Mário Monteiro / Guilherme Cardoso

1347 O contexto funerário do sector da "necrópole NO" da Rua das Portas de S. Antão (Lisboa): o espaço, os artefactos, os indivíduos e a sua interconectividade na interpretação do passado Sílvia Loja, José Carlos Quaresma, Nelson Cabaço, Marina Lourenço, Sílvia Casimiro, Rodrigo Banha da Silva, Francisca Alves-Cardoso

${ }_{1361}$ Povoamento em época Romana na Amadora - resultados de um projeto pluridisciplinar Gisela Encarnação / Vanessa Dias

1371 A Arquitectura Residencial em Mirobriga (Santiago do Cacém): contributo a partir de um estudo de caso Filipe Sousa / Catarina Felício

${ }_{1385}$ O fim do ciclo. Saneamento e gestão de resíduos nos edifícios termais de Mirobriga (Santiago do Cacém)

Catarina Felício / Filipe Sousa

1399 Balsa, Topografia e Urbanismo de uma Cidade Portuária Vítor Silva Dias / João Pedro Bernardes / Celso Candeias / Cristina Tété Garcia

1413 No Largo das Mouras Velhas em Faro (2017): novas evidências da necrópole norte de Ossonoba e da sua ocupação medieval Ricardo Costeira da Silva / Paulo Botelho / Fernando Santos / Liliana Nunes

1429 Instrumentos de pesca recuperados numa fábrica de salga em Ossonoba (Faro) Inês Rasteiro / Ricardo Costeira da Silva / Paulo Botelho

1439 A Necrópole Romana do Eirô, Duas Igrejas (Penafiel): intervenção arqueológica de 2016 Laura Sousa / Teresa Soeiro

1457 Ritual, descarte ou afetividade? A presença de Canis lupus familiaris na Necrópole Noroeste de Olisipo (Lisboa)

Beatriz Calapez Santos / Sofia Simões Pereira / Rodrigo Banha da Silva / Sílvia Casimiro / Cleia Detry / Francisca Alves Cardoso

1467 Dinâmicas económicas em Bracara na Antiguidade Tardia Diego Machado / Manuela Martins / Fernanda Magalhães / Natália Botica

1479 Cerâmicas e Vidros da Antiguidade Tardia do Edifício sob a Igreja do Bom Jesus (Vila Nova de Gaia) Joaquim Filipe Ramos

1493 Novos contributos para a topografia histórica de Mértola no período romano e na Antiguidade Tardia Virgílio Lopes

\section{8. Época Medieval}

1511 Cerâmicas islâmicas no Garb setentrional "português": algumas evidências e incógnitas Constança dos Santos / Helena Catarino / Susana Gómez / Maria José Gonçalves / Isabel Inácio / Gonçalo Lopes / Jacinta Bugalhão / Sandra Cavaco / Jaquelina Covaneiro / Isabel Cristina Fernandes / Ana Sofia Gomes 
1525 Contributo para o conhecimento da cosmética islâmica, em Silves, durante a Idade Média Rosa Varela Gomes

1537 Yábura e o seu território - uma análise histórico-arqueológica de Évora entre os séculos VIII-XII José Rui Santos

1547 A encosta sul do Castelo de Palmela - resultados preliminares da escavação arqueológica Luís Filipe Pereira / Michelle Teixeira Santos

1559 A igreja de São Lourenço (Mouraria, Lisboa): um conjunto de silos e de cerâmica medieval islâmica

Andreia Filipa Moreira Rodrigues

1571 O registo material de movimentações populacionais no Médio Tejo, durante os séculos XII-XIII. Dois casos de "sunken featured buildings", nos concelhos de Cartaxo e Torres Novas Marco Liberato / Helena Santos / Nuno Santos

1585 O nordeste transmontano nos alvores da Idade média. Notas para reflexão Ana Maria da Costa Oliveira

1601 Sepulturas escavadas na rocha do Norte de Portugal e do Vale do Douro: primeiros resultados do Projecto SER-NPVD

Mário Jorge Barroca / César Guedes / Andreia Arezes / Ana Maria Oliveira

1619 "Portucalem Castrum Novum" entre o Mediterrâneo e o Atlântico: o estudo dos materiais cerâmicos alto-medievais do arqueossítio da rua de D. Hugo, nํ. 5 (Porto) João Luís Veloso

1627 A Alta Idade Média na fronteira de Lafões: notas preliminares sobre a Arqueologia no Concelho de Vouzela

Manuel Luís Real / Catarina Tente

1641 Um conjunto cerâmico medieval fora de portas: um breve testemunho aveirense Susana Temudo

${ }_{1651}$ Os Lóios do Porto: uma perspetiva integrada no panorama funerário da Baixa Idade Média à Época Moderna em meios urbanos em Portugal

Ana Lema Seabra

1659 O Caminho Português Interior de Santiago como eixo viário na Idade Média Pedro Azevedo

1665 Morfologia Urbana: Um exercício em torno do Castelo de Ourém André Donas-Botto / Jaqueline Pereira

1677 Intervenção arqueológica na Rua Marquês de Pombal/Largo do Espírito Santo (Bucelas, Loures)

Florbela Estêvão / Nathalie Antunes-Ferreira / Dário Ramos Neves / Inês Lisboa

1691 O Cemitério Medieval do Poço do Borratém e a espacialidade funerária na cidade de Lisboa Inês Belém / Vanessa Filipe / Vasco Noronha Vieira / Sónia Ferro / Rodrigo Banha da Silva

1705 Um Espaço Funerário Conventual do séc. XV em Lisboa: o caso do Convento de São Domingos da Cidade Sérgio Pedroso / Sílvia Casimiro / Rodrigo Banha da Silva / Francisca Alves Cardoso

\section{9. Época Moderna e Contemporânea}

1721 Arqueologia Moderna em Portugal: algumas reflexões críticas em torno da quantificação de conjuntos cerâmicos e suas inferências históricas e antropológicas Rodrigo Banha da Silva / André Bargão / Sara da Cruz Ferreira

1733 Faianças de dois contextos entre os finais do século XVI e XVIII do Palácio dos Condes de Penafiel, Lisboa

Martim Lopes / Tomás Mesquita 
1747 Um perfil de consumo do século XVIII na foz do Tejo: O caso do Mercado da Ribeira, Lisboa Sara da Cruz Ferreira / Rodrigo Banha da Silva / André Bargão

1761 Os Cachimbos dos Séculos XVII e XVIII do Palácio Mesquitela e Convento dos Inglesinhos (Lisboa)

Inês Simão / Marina Pinto / João Pimenta / Sara da Cruz Ferreira / André Bargão / Rodrigo Banha da Silva

1775 "Tomar os fumos da erua que chamão em Portugal erua sancta». Estudo de Cachimbos provenientes da Rua do Terreiro do Trigo, Lisboa

Miguel Martins de Sousa / José Pedro Henriques / Vanessa Galiza Filipe

1787 Cachimbos de Barro Caulínitico da Sé da Cidade Velha (República de Cabo Verde)

Rodrigo Banha da Silva / João Pimenta / Clementino Amaro

1801 Algumas considerações sobre espólio não cerâmico recuperado no Largo de Jesus (Lisboa) Carlos Boavida

1815 Adereços de vidro, dos séculos XVI-XVIII, procedentes do antigo Convento de Santana de Lisboa (anéis, braceletes e contas)

Joana Gonçalves / Rosa Varela Gomes / Mário Varela Gomes

1837 Da ostentação, luxo e poder à simplicidade do uso quotidiano: arqueologia e simbologia de joias e adornos da Idade Moderna Portuguesa Jéssica Iglésias

1849 Os amuletos em Portugal - dos objetos às superstições: o coral vermelho Alexandra Vieira

1865 Cerâmicas de Vila Franca de Xira nos séculos XV e XVI Eva Pires

1879 «Não passa por teu o que me pertence». Marcas de individualização associadas a faianças do Convento de Nossa Senhora de Aracoeli, Alcácer do Sal Catarina Parreira / Íris Fragoso / Miguel Martins de Sousa

1891 Cerâmica de Leiria: alguns focos de produção

Jaqueline Pereira / André Donas-Botto

1901 Os Fornos na Rua da Biquinha, em Óbidos Hugo Silva / Filipe Oliveira

1909 A casa de Pêro Fernandes, contador dos contos de D. Manuel I: o sítio arqueológico da Silha do Alferes, Seixal (século XVI) Mariana Nunes Ferreira

1921 O Alto da Vigia (Sintra) e a vigilância e defesa da costa Alexandre Gonçalves / Sandra Santos

1937 O contexto da torre sineira da Igreja de Santa Maria de Loures Paulo Calaveira / Martim Lopes

1949 A Necrópole do Hospital Militar do Castelo de São Jorge e as práticas funerárias na Lisboa de Época Moderna Susana Henriques / Liliana Matias de Carvalho / Ana Amarante / Sofia N. Wasterlain

1963 SAND - Sarilhos Grandes Entre dois Mundos: o adro da Igreja e a Paleobiologia dos ossos humanos recuperados

Paula Alves Pereira / Roger Lee Jesus / Bruno M. Magalhães

1975 Expansão urbana da vila de Cascais no século XVII e XVIII: a intervenção arqueológica na Rua da Vitória no 15 a 17

Tiago Pereira / Vanessa Filipe

1987 Novos dados para o conhecimento do Urbanismo de Faro em época Moderna Ana Rosa 
1995 Um exemplo de Arqueologia Urbana em Alcoutim: o Antigo Edifício dos CTT Marco Fernandes / Marta Dias / Alexandra Gradim / Virgílio Lopes / Susana Gómez Martínez

2007 Palácio dos Ferrazes (Rua das Flores/Rua da Vitória, Porto): a cocheira de Domingos Oliveira Maia

Francisco Raimundo

2021 As muitas vidas de um edifício urbano: História, Arqueologia e Antropologia no antigo Recreatório Paroquial de Penafiel Helena Bernardo / Jorge Sampaio / Marta Borges

2035 O convento de Nossa Senhora da Esperança de Ponta Delgada: o contributo da arqueologia para o conhecimento de um monumento identitário João Gonçalves Araújo / N’Zinga Oliveira

2047 Arqueologia na ilha do Corvo... em busca da capela de Nossa Senhora do Rosário Tânia Manuel Casimiro / José Luís Neto / Luís Borges / Pedro Parreira

2059 Perdidos à vista da Costa. Trabalhos arqueológicos subaquáticos na Barra do Tejo Jorge Freire / José Bettencourt / Augusto Salgado

2071 Arqueologia marítima em Cabo Verde: enquadramento e primeiros resultados do projecto CONCHA

José Bettencourt / Adilson Dias / Carlos Lima / Christelle Chouzenoux / Cristóvão Fonseca / Dúnia Pereira / Gonçalo Lopes / Inês Coelho / Jaylson Monteiro / José Lima / Maria Eugénia Alves / Patrícia Carvalho / Tiago Silva

2085 Trabalhos arqueológicos na Cidade Velha (Ribeira Grande de Santiago, Cabo Verde): reflexões sobre um projecto de investigação e divulgação patrimonial André Teixeira / Jaylson Monteiro / Mariana Mateus / Nireide Tavares / Cristovão Fonseca / Gonçalo C. Lopes / Joana Bento Torres / Dúnia Pereira / André Bargão / Aurélie Mayer / Bruno Zélie / Carlos Lima / Christelle Chouzenoux / Inês Henriques / Inês Pinto Coelho / José Lima / Patrícia Carvalho / Tiago Silva

2103 A antiga fortificação de Quelba / Khor Kalba (E.A.U.). Resultados de quatro campanhas de escavações, problemáticas e perspectivas futuras Rui Carita / Rosa Varela Gomes / Mário Varela Gomes / Kamyar Kamyad

2123 Colónias para homens novos: arqueologia da colonização agrária fascista no noroeste ibérico Xurxo Ayán Vila / José Mạ . Señorán Martín 


\title{
A ARQUITECTURA RESIDENCIAL EM MIROBRIGA (SANTIAGO DO CACÉM): CONTRIBUTO A PARTIR DE UM ESTUDO DE CASO
}

\author{
Filipe Sousa ${ }^{1}$, Catarina Felício ${ }^{2}$
}

\begin{abstract}
RESUMO
O estudo de um edifício habitacional situado na cidade romana de Mirobriga (Santiago do Cacém) permitiu a sua identificação como uma casa de peristilo de planimetria axializada. O edifício incluía ainda um espaço comercial anexo que, numa fase mais tardia, poderá, pela presença de estruturas hidráulicas, ser associado ao tratamento de têxteis.

O cruzamento do estudo dos contextos estratigráficos, da arquitectura e dos faseamentos construtivos forneceu dados acerca da sequência de construção, reformas, abandonos e reocupações do edifício ao longo dos séculos I a IV d.C., contribuindo para a compreensão da evolução urbana da cidade.

Palavras-chave: Arquitectura Romana, Domus, Taberna, Época Flávia, Século III d.C.
\end{abstract}

\begin{abstract}
The study of a residential building in the roman city of Mirobriga (Santiago do Cacém, Portugal) led to the its identification as an axis orientated peristyle house. The building had commercial or productive facility as well, attached to the residential block, that possibly worked, in a later phase, on a textile related activity.

The cross study of stratigraphic contexts, architecture and construction phases provided information regarding the building's sequence of construction, reform, abandonment and reoccupation throughout the $1^{\text {st }}$ to $4^{\text {th }}$ centuries, allowing for a better understanding of this city's urban development.
\end{abstract}

Keywords: Roman Architecture, Domus, Taberna, Flavian Period, $3^{\text {rd }}$ century A.D.

\section{INTRODUÇÃO}

O estudo que aqui se apresenta teve por base uma casa de peristilo situada na cidade romana de Mirobriga. Este estudo englobou uma análise estratigráfica completa, tendo em vista o conhecimento da sua diacronia, assim como um estudo fundamentado aos compartimentos identificados. A abordagem às técnicas construtivas, apesar de ter constituído um objectivo de base, excede o alcance deste artigo, pelo que será alvo de uma publicação independente.

$\mathrm{O}$ edifício em questão, inicialmente designado como "Casa da Calçada" (Barata 1996) e posteriormente referido como "construção de átrio" (Barata
1999) e "Construção 3" (Quaresma 2012), foi escavado parcialmente nos anos de 1995 e 1996 por Filomena Barata, tratando-se de uma escavação de diagnóstico com vista à identificação de um local adequado à implantação do Centro Interpretativo (Barata 1996:3).

Embora parcial, a escavação revelou um edifício de planta centralizada por um pátio porticado, encontrando-se bastante mal conservado a todos os níveis, com excepção do muro limite situado a oeste (Barata 1996: 7), com uma altura conservada de cerca de 1,60 m, ao qual se adossa uma escadaria que também se conserva parcialmente e que terá contribuído para a conservação do muro.

\footnotetext{
1. (FCSH-UNL); filipe.alb.sousa@gmail.com

2. (FCSH-UNL); catarina.m.felicio@gmail.com
} 
A análise estratigráfica revelou cinco momentos na vida do edifício assim como quatro fases construtivas das quais apenas a primeira e a última dizem respeito ao corpo principal do edifício, sendo as restantes fases adscritas ao corpo oeste, um pequeno espaço comercial ou oficinal que, para a primeira fase, carece de elementos de caracterização. Foi ainda identificada uma última fase de utilização do espaço, numa época em que a casa já estaria em avançado estado de ruína, nomeadamente uma possível oficina de transformação metalúrgica (Sousa 2018: 107-108).

\section{A EVOLUÇÃO ARQUITECTÓNICA DA CASA}

\subsection{A $1^{\underline{a}}$ fase: $80-110$ d.C}

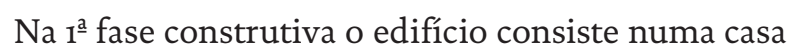
de peristilo onde foram identificados 12 ambientes, tendo como anexo, do lado oeste, um pequeno compartimento, o ambiente 1 , que pelas dimensões do vão de acesso e respectiva soleira, foi-lhe atribuída uma funcionalidade comercial ou oficinal (Figura 2). A conformação inicial do edifício é assim constituída por um corpo principal de função residencial e um segundo corpo, substancialmente menor, de função comercial ou oficinal (Sousa 2018: 86 e 23).

\subsubsection{A casa e o seu enquadramento tipológico}

A casa apresenta uma planta de tendência axializada, estando o triclinium encostado ao alçado Oeste, descentrado do enquadramento cénico proporcionado pelas colunas do peristilo. O vestibulum situa-se à direita desse eixo, também descentrado, quer relativamente ao enquadramento das colunas do peristilo quer relativamente ao vão de acesso ao triclinium.

Embora não totalmente conseguida, eventualmente devido a limitações do projecto, a sua planimetria encontra paralelo nos modelos de planta perfeitamente axializada, tais como a Casa de los Pájaros, em Italica (Garcia y Bellido 1960: fig.8 apud Beltrán 2003: 36), a Casa del Cuadrante, em Baelo (Silliéres 1991: fig.2 apud Beltrán 2003: 33), a Casa dos Repuxos ou a Casa de Cantaber, em Conimbriga (Correia 2013: 107 e 92) e que vem a ser característica a partir dos inícios do século I d.C., pela presença do eixo vestibulum/peristylum/triclinium, encontrando-se as dependências privadas, os cubicula, situadas em redor do peristilo (Beltrán 2003: 33-34; Farrar 2011: 16-17).

A atribuição tipológica de Casa de peristylum em vez de Casa de atrium é motivada pela identificação dos compartimentos que compõem este eixo. Por outro lado, a designação de átrio acarreta implicações e conotações de cariz sociocultural que não se adequam a espaços criados nesta cronologia.

Até ao Principado as habitações apresentam a disposição tradicional fauces-atrium-tablinum, sendo o ritual da salutatio realizado no atrium. Com o advento do Principado e consequentes transformações sociais, que ditaram a diversificação dos papéis sociais dos diferentes ambientes da casa (Beltrán 2003: 25) este modelo de habitação cai em desuso. O tablinum é substituído pelo triclinium enquanto sala de representação e aparato que preside ao peristilo. $\mathrm{O}$ atrium cai em desuso e, segundo alguns autores, é, aparentemente, substituído pelo vestibulum enquanto sala de recepção e distribuidora de circulação existindo, por vezes, bancos destinados aos que aguardavam ser recebidos (Beltrán 2003: 31; Farrar 2011: 17 e 19). O tablinum é lateralizado, ou colocado numa área da casa mais privada, sendo possível a sua identificação com a exedra, como é o caso da Casa dos Repuxos, da Casa do Medianum Absidado e da Casa de Cantaber, em Conimbriga (Beltrán, 2003, p.29; Correia, 2013, p.182) e da Casa del Mitreo, em Emerita Augusta, sendo que neste último caso o autor propõe a designação de tablinum (Corralez Álvares, 2013, p.211 e 212).

\subsubsection{Os compartimentos e estruturação interna}

\subsubsection{O vestibulum}

$\mathrm{O}$ acesso à habitação a partir da via seria efectuado pelo ambiente 3, o vestibulum. A sua leitura enquanto vestibulum (Ginouvès 1998: 157) prende-se, por um lado, pelas suas proporções de $12 \times 12$ pés $(352 \mathrm{cmx} 351 \mathrm{~cm})$ e pela sua posição quase centralizada na fachada da casa que comunica com a via. $O$ vão de acesso ao peristilo é duplo, centralizado por um pilar de planta quadrangular, segundo a morfologia do alicerce que ainda se conserva, estruturando duas passagens independentes (Sousa 2018: 79), à semelhança dos vestibula da Casa dos Repuxos (Correia 2013: 105-107) e da Casa de Cantaber, em Conimbriga (Correia 2013: 92-93), embora de dimensões mais modestas.

Tal como proposto por vários autores, este espaço poderá ter funcionado como o local onde visitantes e clientes aguardariam ser recebidos pelo seu patronus, podendo também ser o local da salutatio (Correia 2010: 196; Farrar 2011: 17 e 19). 


\subsubsection{O peristylum}

A identificação de dois quadrantes de coluna caídos na zona norte do ambiente 6 , associada à morfologia planimétrica do espaço, permite a sua identificação com uma área porticada.

Apesar de não ser evidente qual o número de colunas que terão existido, a necessidade de suportar a cobertura pressupõe a existência de pelo menos quatro, uma em cada canto, embora seja expectável a existência de mais colunas no lado mais comprido do muro estilóbato, presumivelmente 3 , pela necessidade de transpor uma maior distância de cobertura. Esta quantidade e disposição de colunas $3 \times 2$ é também sugerida no peristilo da Casa Periquito, igualmente situada em Mirobriga, verificando-se o interface de assentamento das colunas centrais, em falta à época da sua escavação (Kopf 2018: fig.68).

A divisão entre o ambulatorium e a área sem cobertura é efectuada por um muro estilóbato ou pluteus (com uma altura estimada de cerca de $85 \mathrm{~cm}$ ), sobre o qual foram construídas as colunas. Este elemento é característico das casas de peristilo tendo surgido, inicialmente, como uma cerca, colocada entre as colunas, dando mais tarde lugar a um muro, também construído entre as colunas, cuja principal função seria, possivelmente, a de impedir as águas pluviais de alcançar o ambulatorium e os compartimentos anexos (Farrar 2011: 30).

Quer o ambulatorium quer a área sem cobertura seriam pavimentadas a opus siginum colocado directamente sobre o nível rochoso, conservando-se ainda o nível de preparação no ambulatorium. A pavimentação do espaço descoberto repercute-se na maioria dos peristilos escavados em Mirobriga. Esta solução construtiva poderá ter sido motivada pela a inexistência de níveis de solo que possibilitassem o crescimento de plantas, inviabilizado a existência de um jardim na área exterior.

Em todo o caso, existe a possibilidade, embora ainda não comprovada arqueológicamente, de estes espaços pavimentados terem possuído vasos com plantas de forma a embelezar o espaço (Farrar 2013: 20). O pavimento impermeável facilitaria a recolha das águas pluviais e sua condução para o exterior do edifício, tendo sido identificado, na base do muro estilóbato, UEM 20, o ponto de recolha da canalização $\mathrm{C}$ 17, que seguia para norte e desaguava numa outra canalização, a C18, situada no exterior da casa e que encaminhava a água para sul (Sousa 2018: 48 , 49 e 89).

\subsubsection{O triclinium}

$\mathrm{Na}$ Casa da Calçada as dimensões $(6,57 \mathrm{~m} \mathrm{x} \mathrm{8,37} \mathrm{m)}$ e morfologia do ambiente 7 , assim como a sua localização axializada na casa, permitem a sua identificação como triclinium (Sousa 2018: 90-92).

A localização destes espaços no eixo central da casa e com vão aberto para o peristilo, bem como a sua morfologia e dimensões podem ser utilizados como elementos para a identificação destes como triclinia, por vezes auxiliada pela presença de mosaicos (Dunbabin 2003: 41-42; Uribe Agudo 2009: 155). Em condições ideais, os triclinia podem ser identificados pela estruturação da sua decoração parietal ou dos pavimentos que teria como função demarcar a área na qual se desenrolaria o banquete da área de entrada ou recepção (Guiral Pelagrín e Mostalac Carrillo: 1993; Uribe Agudo 2009: 55; Correia 2019: 187-188). Aproximandamente $2 / 3$ do espaço era dedicado à colocação dos lecti triclinares, sendo o restante 1/3 destinado à área de entrada ou recepção (Uribe Agudo 2009: 155). Esta repartição é notória ao nível dos pavimentos musivos destinados a estes espaços, com reflexo num padrão $T+U$, sendo o " $U$ " reservado à colocação dos lecti em redor de um tapete central (Dunbabin 2003: 41-42; Uribe Agudo 2009: 156-158; Correia 2010: 187-188).

$\mathrm{Na}$ ausência destes elementos arquitectónicos e/ou decorativos, podemos apenas, por meio de comparação com exemplares mais completos e que apresentam as mesmas proporções, inferir que os mesmos princípios de ocupação e utilização do espaço se terão verificado.

\subsubsection{Os cubicula}

Este tipo de compartimentos distingue-se normalmente pela divisão do espaço interno em duas partes: uma destinada ao lectus, correspondendo a $1 / 3$ do espaço e outra constituindo uma antecâmara correspondendo a 2/3 do espaço (Guiral Pelegrín 2018: 621 ). Esta hierarquização dos espaços pode ser marcada quer pela estruturação dos pavimentos, tectos ou pinturas murais cujos esquemas decorativos procuram demarcar esta divisão, quer pela existência de pilastras a demarcar ambos os espaços (Guiral Pelegrín 2018: 621). A forma mais comum de identificação de cubicula prende-se pela demarcação, em pavimentos de mosaico, daquela que seria a posição do mobiliário, no caso o lectus (Correia 2013: 191192; Corralez Álvares 2016: 212-213).

No caso em estudo, foram interpretados como $\mathrm{cu}$ - 
bicula os ambientes 2, 8 e 16, que apresentam dimensões semelhantes entre si, $3,55 \mathrm{~m} \times 3,26 \mathrm{~m}$, com excepção do ambiente 2 que apresenta uma largura menor $(2,96 \mathrm{~m})$, correspondendo a uma planimetria de tendência quadrangular. Apesar de não existirem soleiras conservadas ou qualquer outro indício da localização dos vãos de acesso, este deveria efectuar-se por um vão aberto para o peristilo, como é a norma nas casas de peristilo (Sousa 2018: 92).

Apesar de neste caso não se conservarem os elementos arquitectónicos ou decorativos que normalmente atribuídos aos cubicula, a sua localização na casa e dimensões encontram paralelo em vários compartimentos identificados como cubicula em casas de planimetria similar, como é o caso da Casa de los Marmoles, em Augusta Emerita, cujos compartimentos apresentam planta tendencialmente quadrangular com medidas de $3,6 \mathrm{om}$ de comprimento por $3,80 \mathrm{~m}$ de largura, sendo o seu acesso realizado por um vão aberto para o peristilo; da designada Casa V/A, na mesma cidade, onde foram identificados compartimentos com metrologia análoga, também interpretados como cubicula (Corrales Álvarez 2016: 224) ou a Casa dos Repuxos, nomeadamente os compartimentos, ํo 26 e ํㅜ 27 , identificados como cubicula devido à estrutura evidenciada pela decoração dos pavimentos musivos (Correia 2013: 109 e 218) e que apresentam medidas de cerca de $4,56 \mathrm{~m}$ de comprimento por $3,8 \mathrm{om}$ de largura.

Neste último exemplo salienta-se ainda que a localização dos cubicula, relativamente ao pseudo-peristylum do ninfeu, é bastante semelhante à verificada na Casa da Calçada.

\subsubsection{Outros compartimentos}

No sector nordeste do edifício existem dois compartimentos cuja identificação não é inequívoca. $\mathrm{O}$ ambiente 9, de configuração rectangular e estreita, poderá tratar-se de uma culina pela sua localização anexa ao triclinium. A identificação de compartimentos anexos a triclinia como culinae encontra paralelo em outros exemplares hispanos, como é o caso da Casa del Pretorio, em Arcobriga (Uribe Agudo 2008: 56), da Domus 2, de Bilbilis (Idem: 109 e 112), da Casa de los Delfines, em Celsa (Idem: 206 e 210), da Casa de Likine, em La Caridad (Idem: 365 e 371), da Casa Villanueva, de Emporiae (Balil Illana 1972: 95 apud Uribe Agudo 2008: 237 e 244).

Em Mirobriga, a culina da Casa 7, compartimento R7.1.4, evidenciada pela existência de um balcão em alvenaria que terá funcionado como estrutura de combustão (Oberhofer 2018b: 110 e 113), apesar de apresentar uma morfologia distinta, encontra-se numa localização análoga à do ambiente 9 .

O ambiente 10 poderia tratar-se de uma cella penaria, acumulando simultaneamente a função de aposentos servis. A proposta de interpretação deste ambiente, se bem que por enquanto especulativa, prende-se com a sua localização na casa, numa zona recuada e oculta, que poderíamos associar a uma área de trabalho ou armazenamento, correspondendo a uma zona de serviço da habitação.

O sector sudeste apresenta também identificação problemática. Os dois ambientes aí identificados, 4 e 17, resultam da reconstituição da planimetria do edifício, não sendo clara a forma como ambos se articulariam. O primeiro poderia tratar-se de uma antecâmara para o segundo no caso de este se aceder pelo interior. Outra hipótese é a de o ambiente 4 se tratar de um outro espaço comercial ou oficinal sendo acedido pela via. $\mathrm{O}$ ambiente 17 apresenta dimensões algo reduzidas para ser interpretado como cubiculum 7 x 12 pés $(2,12 \mathrm{~m} \times 3,57 \mathrm{~m})$ e, embora se localize numa área central da casa, estão ausentes outros elementos que permitam caracterizar a sua funcionalidade.

\subsubsection{Os elementos de datação}

A cronologia proposta para construção da $1^{\underline{a}}$ fase provém do contexto 1, localizado no peristilo. Este contexto corresponde ao interface de destruição ou remoção do pavimento em opus signinum aí existente. A remoção do pavimento, assunto que abordaremos mais aprofundadamente abaixo, resultou num interface que deixou exposto o nível de preparação do referido pavimento, composto por cerâmica britada envolta em argamassa de cal e areia e colocada directamente no afloramento geológico. O conjunto dos materiais recolhidos deste interface sugere uma cronologia de construção situada entre 8o d.C e 100 d.C., podendo alcançar a primeira década do século II d.C. (Figura 7 - Contexto 1) (Sousa 2018: 28-29).

\subsection{A $2^{2}$ fase: $120-150$ d.C.}

A $2^{2}$ fase consistiu numa ampliação do ambiente 1 para norte e na criação de um piso superior. A análise estratigráfica murária permitiu detectar um corte efectuado no cunhal formado pelo muros norte e oeste da $1^{\underline{a}}$ fase, de forma a permitir a inserção do novo muro de fachada oeste no espaço anteriormen- 
te ocupado pelo cunhal. Por sua vez, o muro norte, UEM5, terá sido apenas parcialmente demolido, mantendo-se em utilização na $2^{\underline{a}}$ fase, sendo ainda visível o seu interface de adossamento no muro oeste, UEM23. Contudo, nela terá sido aberto um vão para permitir a passagem para o espaço recém-construído. Nesta reformulação o espaço comercial ou oficinal ficou constituído por 2 ambientes, Ar.1 e A1.2, uma vez que o muro tardoz do espaço anterior, UEM5, continuou em utilização nesta fase (Sousa 2018: 53) (Figura 3).

$\mathrm{O}$ acesso ao piso superior era efectuado por uma escadaria exterior, adossada a oeste ao edifício recém-construído. A restituição da funcionalidade dos ambientes criados nesta fase apresenta-se problemática. Apesar de ser fácil manter a atribuição de uma função comercial ou oficinal aos ambientes 1.2 e 1.2 nesta nova fase, não existem quaisquer dados para a sua caracterização.

Quanto ao piso superior pode colocar-se a hipótese de uma funcionalidade habitacional. A ser o caso, a criação deste novo corpo residencial poderia ser reflexo de alterações na estrutura familiar dos proprietários, por exemplo relativamente aos elementos servis, que poderiam explorar o espaço comercial e habitar no piso superior; ou então a hipótese da criação de um espaço habitacional com vista à sua rentabilização.

\subsubsection{Os elementos de datação}

O principal elemento que permite a atribuição de uma cronologia à $2^{\underline{a}}$ fase consiste num depósito votivo de cariz fundacional identificado no ambiente 1.2. (Sousa 2018: 29-30). O depósito consiste num recipiente tipo tigela ou prato-tampa, dentro do qual foram colocados os ossos de uma ave (Barata 1999: 56). O recipiente, correspondente à forma III-A, da variante 1, com uma cronologia situável entre os meados do século I d.C. e os meados do século II d.C. (Pinto 2003: 220 - 225), encontrava-se depositado em posição invertida funcionando como "tampa” de uma pequena cova escavada no afloramento (Barata 1999: 56-57). De uma outra depressão escavada no afloramento, com cerca de $20 \mathrm{~cm}$ de diâmetro, foi também recolhido um bronze de Adriano (117 - 138 d.C.) (Mir-568-oor), pelo que, considerando a cronologia de construção da primeira fase, a construção da $2^{\circ}$ fase terá tido lugar na $1^{\circ}$ metade do século II d.C. (Figura 7 - Contexto 2).

\subsection{A $3^{\mathrm{a}}$ fase: $150-250$ d.C.?}

Também nesta fase apenas se verificam transformações no corpo comercial do edifício. Estas consistiram no aumento do edifício novamente para norte, em ambos os pisos, sendo que nesta fase o espaço comercial é dotado de estruturas hidráulicas destinadas ao funcionamento de uma actividade produtiva (Sousa 2018: 86-87).

Destas estruturas conservam-se apenas duas concavidades escavadas no afloramento, uma de grandes dimensões, encostada ao muro UEM26, e outra mais pequena situada a sudeste da anterior. Ambas as concavidades eram escoadas por duas canalizações independentes, as $\mathrm{C}_{4} 4$ e C16, que desaguavam numa outra, C15, que despejava o conteúdo das anteriores directamente na via (Sousa 2018: 58-59) (Figura 4).

\subsubsection{Compartimentos e estruturação interna}

O espaço comercial encontra-se dividido em, pelo menos, duas áreas que constituiriam áreas de trabalho distintas. A área junto à entrada corresponde ao antigo compartimento da $\mathrm{I}^{\mathrm{a}}$ fase e não regista nenhuma característica que possa levar à sua funcionalidade. Para lá deste compartimento funcionavam as estruturas hidráulicas. $O$ seu estado de conservação não permite, todavia, uma interpretação segura da sua funcionalidade, embora se coloque a possibilidade de uma funcionalidade associada ao tratamento de têxteis (Sousa 2018: 86-88).

\subsubsection{Elementos de datação}

Não existem dados cronológicos absolutos para esta fase. A sua construção ter-se-á efectuado num período incerto após os meados do século II d.C. e anterior aos meados do século III d.C., intervalo cronológico apontado de forma relativa pelas datações da fase anterior e posterior.

\subsection{A $4^{\mathrm{a}}$ fase: 275 ? -325 ? d.C.}

A esta fase correspondem algumas transformações visíveis em toda a área do edifício que consistem, na maioria dos casos identificados, em subdivisões de compartimentos já existentes e eliminação de alguns vãos de passagem. Esta reformulação terá sido efectuada após um período de abandono do edifício, situado algures na $2^{\underline{a}}$ metade do século III d.C., possivelmente de algumas décadas, período após o qual o edifício é reocupado ainda na $2^{\underline{a}}$ metade deste século. As razões que motivam a hipótese de ter exis- 
tido um período de abandono, anterior a esta fase, prendem-se não só com a aparente distância "cultural" e tecnológica que parece verificar-se nesta reformulação, relativamente à ocupação do edifício, que rompe com a configuração da construção anterior; mas também o facto de os dados disponíveis apontarem para que o ambiente 7 se encontrasse já em ruína numa época anterior à a $1^{\mathrm{a}}$ metade do século IV d.C. o que poderá ter motivado o fecho do vão de acesso ao triclinium de forma a excluir esta área da casa do espaço agora ocupado. Os novos ocupantes não terão procurado manter o status quo do edifício nem a funcionalidade da compartimentação original. Estas reformulações aparentam aproveitar o edificado pré-existente como elemento de apoio.

A subdivisão mais marcante é a efectuada no peristilo, na qual este espaço é dividido em duas partes desiguais pela construção de um muro, UEM $31+32$, que o atravessa no sentido este/oeste. No ambulatorium sul identificaram-se 4 possíveis buracos de poste (Barata 1996: 10), em aparente associação ao muro, 3 dispostos paralelamente a este a uma distância de 2,71 metros (buraco 1) e 2,60 metros (bura$\cos 2$ e 3), distando entre si 2,70 metros (buraco 1 e 2) e 1,38 metros (buraco 2 e 3 ), e um no ambulatorium oeste, o $\mathrm{n}^{\circ} 4$. Este último encontra-se alinhado com o nํำ, alinhamento que se salienta pela existência de um sulco que aparenta conectar ambos os buracos (Figura 5 e 6). A distância entre o muro UEM $31+32$ e o alinhamento de buracos ( 1,2 e 3 ) é a mesma que entre o referido muro e a UEM19, o que parece indicar alguma racionalidade nesta transformação, embora o seu propósito não seja claro. Estes não parecem ser consistentes com buracos de andaime colocados aquando da construção da casa, uma vez que teriam sido identificados mais buracos semelhantes em todos os corredores do peristilo distribuídos num padrão similar.

A análise à distribuição dos buracos sugere que estes poderão corresponder ao local de implantação de postes de auxílio ao suporte do travejamento do peristilo (Barata 1999: 56) (localização estimada do travejamento), num período em que a estrutura apresentaria sinais de ruína (Figura 5). Esta solução não discorda do carácter rudimentar das restantes reformulações desta fase, pelo que poderá estar associada. A existência de um sulco que aparenta conectar os buracos 1 e 4, poderia, por outro lado, apontar o local de implantação de uma subdivisão efectuada por meio de um taipal de madeira, embo- ra não tenha sido identificado nenhum outro sulco a conectar os restantes buracos. Observa-se, também, que o posicionamento do buraco 4, a corresponder a um travejamento superior, apresenta a mesma distribuição no espaço que o muro $\mathrm{UEM}_{31+32}$, sendo ambos equidistantes das UEMig e 21, o que parece reforçar a hipótese distributiva dos travejamentos e localização dos buracos enquanto local de postes de suporte, admitindo-se ainda a hipótese de terem acumulado outras funcionalidades como elementos de apoio a divisórias de madeira.

Outra das subdivisões desta fase é a realizada nos ambientes 1.1 e 2. Esta consiste na construção de um muro, UEM29, perpendicular à soleira do vão de acesso ao ambiente 1.1, criando uma divisão este-oeste, originando em dois novos ambientes $1.5 \mathrm{e}$ 1.6. Este muro divisor articulava-se com o muro de entaipamento desse vão, visível na documentação das escavações, mas, entretanto, desmontado. Este entaipamento foi documentado apenas do lado oeste da porta, sendo uma reformulação comum em edifícios comerciais desta cidade. Presumivelmente, o acesso ao ambiente 1 terá continuado a existir a partir da via, tendo de ser efectuado pelo local onde passa a canalização da $3^{\underline{a}}$ fase, à direita do entaipamento. Uma terceira subdivisão foi criada a este da anterior originado no ambiente 1.6. Para tal, foi realizada a demolição parcial da UEM9, presumivelmente até ao interface de ligação com a UEM8, tendo posteriormente sido construído um outro troço de muro, cerca de $30 \mathrm{~cm}$ a este, a $\mathrm{UEM}_{3} \mathrm{O}$, roubando espaço ao ambiente 2. Esta reformulação terá permitido a comunicação entre o ambiente $1.5 \mathrm{e} o$ peristilo, que nesta fase continuaria a existir, passando pelo ambiente 2 .

Uma outra subdivisão, detectada no ambiente 1.4, foi realizada mediante a construção de um troço de muro, UEM 33 , do qual apenas restam dois elementos pétreos colocados lado-a-lado. Estes sobrepõem-se a uma pequena vala de implantação com cerca de $4 \mathrm{~cm}$ de profundidade, prolongando-se esta por cerca de 1,40m e curvando ligeiramente para este. Esta nova unidade adossa-se perpendicularmente à UEM27, a uma distância de 1,9om da UEM9, dando origem a um pequeno compartimento a Este, $\mathrm{o}$ ambiente 1.7, cuja configuração não pode ser indubitavelmente restituída.

O outro entaipamento, a UEM28, foi documentado no vão de acesso ao ambiente 7 . Esta reformulação destaca-se das anteriores do ponto de vista constru- 
tivo uma vez que é composto por pedaços de opus signinum reaproveitados. Ocupa toda a largura do vão e impediu o acesso ao ambiente 7 a partir do peristilo. Com efeito, há indícios de que este compartimento deveria estar já em ruína na época em foram efectuadas estas reformulações, conforme se verá de seguida, razão que terá motivado o seu isolamento da área agora em utilização.

\subsubsection{Compartimentos e estruturação interna}

É desconhecida a funcionalidade destas novas compartimentações, embora se encontrem exemplos semelhantes onde as subdivisões são efectuadas com vista à obtenção de várias unidades de habitação destinadas a várias famílias (Ellis 1988: 568 ), sendo que noutros caso a sua função é apenas referida como tendo cariz habitacional (Perich Roca 2014: 141-142; Olesti Vila et alii 2014: 140 e 212). Seja como for, a fragilidade não só das estruturas de subdivisão, mas também a do edificado original, pelo seu estado ruinoso, não permitiu a sua existência de forma continuada no tempo, verificando-se o seu abandono e ruína possivelmente nas primeiras décadas do século IV d.C. (Sousa 2018: 40).

\section{3. ÚLTIMA UTILIZAÇÃO DO ESPAÇO}

A interpretação para a última utilização do espaço é sugerida por dados algo frágeis que não permitem uma leitura inequívoca do seu significado. Neste último momento a maior parte da área sul do edifício aparenta ter sido arrasada para a implementação de uma área de trabalho metalúrgico. Este dado é sugerido pela ausência de derrubes de telhado e de alvenaria na área sul da casa. Esta constatação poderá dever-se por um lado, à acção de nivelamento de forma a acomodar o novo espaço que removeu as paredes eventualmente ainda existentes, assim como os derrubes de alvenaria e telhado da casa, que poderá ter sido conciliada com actividades de espoliação. A essas actividades acrescentam-se eventuais processos pós-deposicionais que também não facilitaram a conservação de grande parte das estruturas de alvenaria na área sudeste da casa, verificando-se os únicos contextos de derrube de telhado indubitavelmente associáveis ao edificado original na zona norte do edifício (triclinium e ambulatorium norte). Tendo em conta os dados referidos, é possível aventar a hipótese de uma outra fase de abandono, época em que terá ocorrido o colapso de algumas áreas do edifício e na qual se parece verificar o arrasamento do edificado anterior, nomeadamente na área sul do edifício.

Alguns dos materiais presentes nessa área consistiam em carvões e pingos de metal em liga de cobre recolhidos de uma concavidade no afloramento, bem como uma grande concentração de escória metálica, contexto sugestivo da existência de uma actividade de transformação metalúrgica (Barata 1999: 56; Sousa 2018: 107-108), assim como um pondus recolhido de outra concavidade próxima (Barata 1996: 11), cuja associação ao contexto não é comprovável .

Com excepção da área sul, todas as restantes áreas constituiriam agora a envolvente da possível oficina, tendo estas sido alvo de despejos de lixos diversos, nomeadamente os ambientes 1 (contextos 3 e 4 ), 5 e 6 norte (contextos 5, 8 e 9) e 7 (contexto 6) (Figura 7), tendo sido aí recuperados fragmentos de escória estratigraficamente associados a materiais da $1^{\mathfrak{a}}$ metade do século IV d.C., sugerindo que terá sido neste período que a oficina terá laborado, depositando os resíduos nas áreas envolventes. Não foram recuperados materiais posteriores aos meados do século IV d.C. sugerindo o fim da utilização do espaço e o seu completo abandono (Sousa 2018: 30 - 42).

\section{CONSIDERAÇÕES FINAIS}

As características arquitectónicas e planimétricas diagnosticáveis na Casa da Calçada afiguram-se como elementos identitários de uma cultura construtiva transversal às casas de peristilo da cidade de Mirobriga, observável na organização interna dos edifícios, bem como na proporção dos peristyla e triclinia, sugerindo a existência de modelos arquitectónicos padronizados nas habitações.

Estas semelhanças poderão prender-se com o facto de todos os edifícios datados até ao momento terem sido construídos numa mesma cronologia, no caso, Flávia (Sousa 2018; Oberhofer 2018a e b; Kopf 2018a e b), sugerindo a existência de uma corrente/escola arquitectónica comum na cidade ou mesmo um programa construtivo residencial.

Por sua vez, a identificação de um dos ambientes como espaço comercial/oficinal de consideráveis dimensões afigura-se como uma novidade numa zona da cidade antes genericamente designada como habitacional, atestando a convivência de distintas funções num mesmo edifício.

A análise da sequência estratigráfica da Casa da Cal- 
çada e respectivos processos de formação, permitiu a identificação de cinco grandes momentos na vida deste edifício: $\mathrm{O}$ primeiro corresponde à sua construção e utilização enquanto domus, englobando as fases 1,2 e 3, num período situável entre a plena Época Flávia e, possivelmente, meados do século III d.C., período no qual se inclui a utilização e respectivas reformulações da taberna. O segundo momento consiste num período de abandono situado nos meados ou na $2^{\underline{a}}$ metade do século III d.C., que poderá ter durado algumas décadas. Ainda na $2^{\underline{a}}$ metade desse século o edifício é reocupado, configurando o terceiro momento, no qual foram efectuadas as reformulações correspondentes à $4^{a}$ fase, seguindo-se, aparentemente, um segundo período de abandono, época em que terá ocorrido o colapso de algumas áreas do edifício e na qual se parece verificar o arrasamento e/ou espoliação de parte do edificado.

No decorrer, ou pouco após a formação destes contextos de abandono, na $1^{\underline{a}}$ metade do século IV d.C, esta zona, agora completamente em ruínas, é aparentemente reocupada enquanto possível espaço de produção metalúrgica.

Posteriormente a esta fase, não se detectaram momentos de ocupação. O abandono total desta área, onde se situara a Casa da Calçada, pode ser datado da $1^{\underline{a}}$ metade do século VI d.C., de acordo com a presença de uma terra sigillata foceense tardia da forma Hayes $3 \mathrm{H}$ numa unidade coluvionar de superfície na zona do ambiente 7 , demonstrando a sua posterioridade ao colapso da estrutura e aos níveis de abandono que se encontram em associação às actividades metalúrgicas (Sousa 2018: 107-108).

Os momentos finais da Casa da Calçada, situáveis a partir dos meados do século III d.C., são pautados por uma descaracterização funcional e arquitectónica, intermitente com períodos de abandono (Sousa 2018: 102-107), que se associa ao fenómeno de crise urbana das cidades clássicas com lugar a partir dos finais do século II d.C. (Gurt Esparraguera 2002). Esta situação é também evidenciada pelo estudo de outros edifícios de Mirobriga. O abandono dos edifícios balneários ter-se à verificado a partir da $2^{\underline{a}}$ metade do século III d.C., estando ausentes materiais posteriores ao início do século IV d.C. (Biers 1988: 108 a 112). Outros edifícios, Construção 1 e 2 (Quaresma 2012), de interpretação mais problemática (Felício 2019: 30-37) também apresentam transformações datadas do século III d.C. (Quaresma 2012: 38 e 55) que, no caso da Construção 1, constituiu a desactiva- ção de um conjunto de canalizações e a criação de um novo nível de circulação em terra (Quaresma 2012: 55). Os restantes edifícios habitacionais estudados possuem cronologias de abandono que se situam no século III d.C. como são o caso da Casa 7 (Oberhofer2018a: 121-123; Peña Cervantes et al 2018: 206-207), da Casa 8, também com algumas reformulações análogas ao caso aqui apresentado (Oberhofer 2018b: 128 e 145; Peña Cervantes et al 2018: 208-209) e, possivelmente, da Casa Periquito (Felício 2019: 49). A estes dados, somam-se os indícios cronológicos para o abandono/sedimentação se algumas vias, também enquadráveis nos meados do século III d.C. (Arthur 1983: 61-72; Oberhofer 2018b: 128 e 145; Peña Cervantes et al 2018: 208-209; Felício 2019: 26-27).

A perspectiva veiculada pela informação arqueológica aponta para um fenómeno algo generalizado na Hispania, embora ainda mal compreendido, caracterizado pelo abandono e desmantelamento de edifícios públicos bem como o abandono de grande parte das áreas habitadas (Gurt Esparraguera 2002: 451). Fortemente vinculado à designada Crise do Século III d.C. pela tradição historiográfica (Járrega 2008: 106 a 109), o fenómeno tem início ainda no final do século II d.C., como nos casos de Cartago Nova (Ramallo Asensio e Quevedo Sánchez, 2015, p.164) ou Iulia Livica (Olesti Vila et alii, 2014, p.84), prolongando-se pelo século III d.C. em inúmeras outras cidades como Barcino (Olesti Vila et alii, 2014, p.140), Baelo Claudia (Olesti Vila et alii, p.212) ou Tarraco (Gurt Esparraguera 2002: 445).

Face aos dados existentes, a Casa da Calçada afigura-se como um microcosmo da evolução urbana da cidade. Construída na Época Flávia, no que aparenta ter sido período de grande prosperidade ao nível da arquitectura doméstica mirobriguese, as ampliações e transformações do seu espaço comercial ao longo do Alto-Império poderão ser o reflexo de uma época de vitalidade. Por outro lado, as etapas de abandono e reocupação verificadas a partir de cerca dos meados do século III d.C. espelham os dados que têm vindo a ser identificados noutros pontos da cidade, repercutindo um fenómeno de transformação urbana vasto e complexo.

\section{AGRADECIMENTOS}

Os autores gostariam de agradecer à equipa do Centro Interpretativo de Mirobriga, a Manuela de Deus e a Filomena Barata. 


\section{BIBLIOGRAFIA}

BALIL ILLANA, A. (1972) - Casa y urbanismo en la España antigua, BSAA, 38 , pp. 55-131.

BARATA, Filomena (1996) - Escavações 1995/95 - Continuação dos relatórios preliminares entregues ao IPPAR em Março de 1996 (Informação nº 240/DA/96) e Outubro de 1996 (Inf. №20/FB/96).

BARATA, Maria Filomena (1999) - As habitações de Miróbriga e os ritos domésticos romanos, Revista Portuguesa de Arqueologia, Lisboa, Volume 2, № 2.

BELTRÁN, Miguel (2003) - La casa hispanorromana. Modelos, in Bolskan, № 20, pp. 13-63.

CORRALES ÁlVAREZ, Álvaro (2016) - La Arquitectura Doméstica de Augusta Emerita, Anejos de AEspa LXXVI, Archivo Español de Arqueologia, CSIC.

CORREIA, Virgílio Nuno Hipólito (2010) - A Arquitectura Doméstica de Conimbriga e as Estruturas Económicas e Sociais da Cidade Romana, Tese de Doutoramento em História, Especialidade em Arqueologia apresentada à Faculdade de Letras da Universidade de Coimbra sob a orientação do Prof. Doutor Jorge de Alarcão, Coimbra.

DUNBABIN, Katherine (2003) - The Roman Banquet - Images of Conviviality, Cambridge University Press.

ELLIS, Simon P. (1988) - The End of the Roman House, in American Journal of Archaeology, Vol.92, № 4, pp. 565-576.

FARRAR, Linda (2013) - Ancient Roman Gardens, The History Press.

FELÍCIO, Catarina (2019) - Gestão de resíduos em Mirobriga - O sistema de sneamento (Séculos I - IV d.C.), Dissertação de Mestrado em Arqueologia apresentada à Faculdade de Ciências Sociais e Humanas da Universidade Nova de Lisboa.

GARCÍA Y BELliDO, A. (1960) - Colonia Ælia Augusta Itálica. Madrid.

GINOUVÉS, R., (1988) - Dictionnaire méthodique de l'architecture grecque et romaine vol. III (Paris, CEFR no ${ }^{84}$ ).

GUIRAL PELEGRÍN, Carmen (2018) - Cubicula y triclinia pintados en Hispania: articulación del espacio, sistemas decorativos e iconografía, in PICTORES PER PROVINCIAS II - STATUS QUAESTIONIS, Actes du $13^{\mathrm{e}}$ Colloque de l'Association Internationale pour la Peinture Murale Antique (AIPMA), Colloque international organisé par Yves Dubois, Michel E.Fuchs et Alexandra Spühler à l'Université de Lausanne, Anthropole, du 12 au 16 septembre 2016.

GUIRAL PELEGRÍN, C.; MOSTALAC CARRILLO, A. (1993) - Influencias itálicas em los programas decorativos de cubicula y triclinia de época republicana e alto-imperial em España, Algunos ejemplos representativos, Espacio, Tiempo y Forma, Série I, 6, pp. 365-392.
GURT ESPARRAGUERA, J. M., (2002) - Transformaciones en el tejido de las ciudades hispanas durante la Antigüedad tardía: dinámicas urbanas, Zephyrus, lin-liv, 20oo2001, pp. 443-471.

JÁRREGA, Ramon (2008) - La crisis del segle III a l'àrea compresa entre Tarraco i Saguntum: aproximació a partir de les dades arqueològiques, In El camp al segle III. De Septimi Sever a la Tetrarquia, ESTUDIS SOBRE EL MÓN RURAL D'ÈPOCA ROMANA - 3, Institut de Recerca Històrica. Universitat de Girona Grup de Recerca Arqueològica del Pla de l'Estany, pp. 105-139.

KOPF, Julia (2018) - Archäologische und stratigraphisce untersuchungen zu Haus 5, in Teicnher, Felix (Ed.), Mirobriga, Eine Stadt im fernen Westen des Imperium Romanum, Kleine Schriften aus dem Vorgeschichtlichen Seminar Marburg, Heft 62, Philipps - Universitat Marburg, pp. 58-91.

OBERHOFER, Karl (2018a) - Archäologische und stratigraphisce untersuchungen zu Haus 7, in Teicnher, Felix (Ed.), Mirobriga, Eine Stadt im fernen Westen des Imperium Romanum, Kleine Schriften aus dem Vorgeschichtlichen Seminar Marburg, Heft 62, Philipps - Universitat Marburg, pp. 109-127.

OBERHOFER, Karl (2018b) - Archäologische und stratigraphisce untersuchungen zu Haus 8, in Teicnher, Felix (Ed.), Mirobriga, Eine Stadt im fernen Westen des Imperium Romanum, Kleine Schriften aus dem Vorgeschichtlichen Seminar Marburg, Heft 62, Philipps - Universitat Marburg, pp. 128-147.

OLESTI VILA, Oriol; GUÀRDIA FELIP, Jordi; MERCADAL FERNÁNDEZ, Oriol (2014) - El fin del sueño urbano en Iulia Llivica (Llivia, Cerdaña), in Las Ciudades de la Tarraconense Oriental entre los s. II-IV d.C. - Evolución urbanistica y contextos materiales, editores S. F. Ramallo Asensio e A. Quevedo Sánchez, Universidad de Murcia, Servicio de Publicaciones, pp. 61-88.

PEÑA CERVANTES, Yolanda; JANKOWIAK, Anna; TEICHNER, Felix (2018) - Keramisches fundmaterial haus Mirobriga in Teicnher, Felix (Ed.), Mirobriga, Eine Stadt im fernen Westen des Imperium Romanum, Kleine Schriften aus dem Vorgeschichtlichen Seminar Marburg, Heft 62, Philipps - Universitat Marburg, pp. 199-210.

PERICH ROCA, Arnau (2014) - Las transformaciones urbanas en Tarraco. El ámbito doméstico a finales del alto-imperio, in Las Ciudades de la Tarraconense Oriental entre los s. II-IV d.C. - Evolución urbanistica y contextos materiales, editores S. F. Ramallo Asensio e A. Quevedo Sánchez, Universidad de Murcia, Servicio de Publicaciones, pp. 119-147.

PINTO, Inês Vaz (2003) - A cerâmica comum das villae romanas de São Cucufate (Beja), Universidade Lusíada Editora, Lisboa.

QUARESMA, José Carlos (2012) - Economia antiga a partir de um centro de consumo lusitano. Terra sigillata e cerâmica 
africana de cozinha em Chãos Salgados (Mirobriga?), Estudos e Memórias 4, UNIARQ, Centro de Arqueologia da Universidade de Lisboa.

QUEVEDO SÁNCHEZ A.; RAMALLO ASENSIO S. F. (2015) - Urbanisme Civique en Temps de Crise - Les Espaces Publiques D'Hispanie et de L'Occident Romain entre le II et le III siècle, Collection de la Casa de Velazquez, Vol. 149.

SILLIÉRES, P. (1991) - La maison romaine a Belo Claudia, Essai de revision des donnes anciennes, Actas de la casa urbana hispanoromana, Zaragoza, pp. 321-328.
SOUSA, Filipe (2018) - A Casa da Calçada - Mirobriga: Diacronia de um edifício habitacional de Época Romana, Dissertação de Mestrado apresentada à Faculdade de Ciências Sociais e Humanas da Universidade Nova de Lisboa.

URIBE AGUDO, P., (2008) - La edilicia doméstica urbana romana en el cuadrante Nordeste de la Península Ibérica (ss. I a.C. - III d.C.), Universidad de Zaragoza (Ciencias de la Antigüedad), <http://zaguan.unizar.es/record/189o> (tesis doctoral inédita).

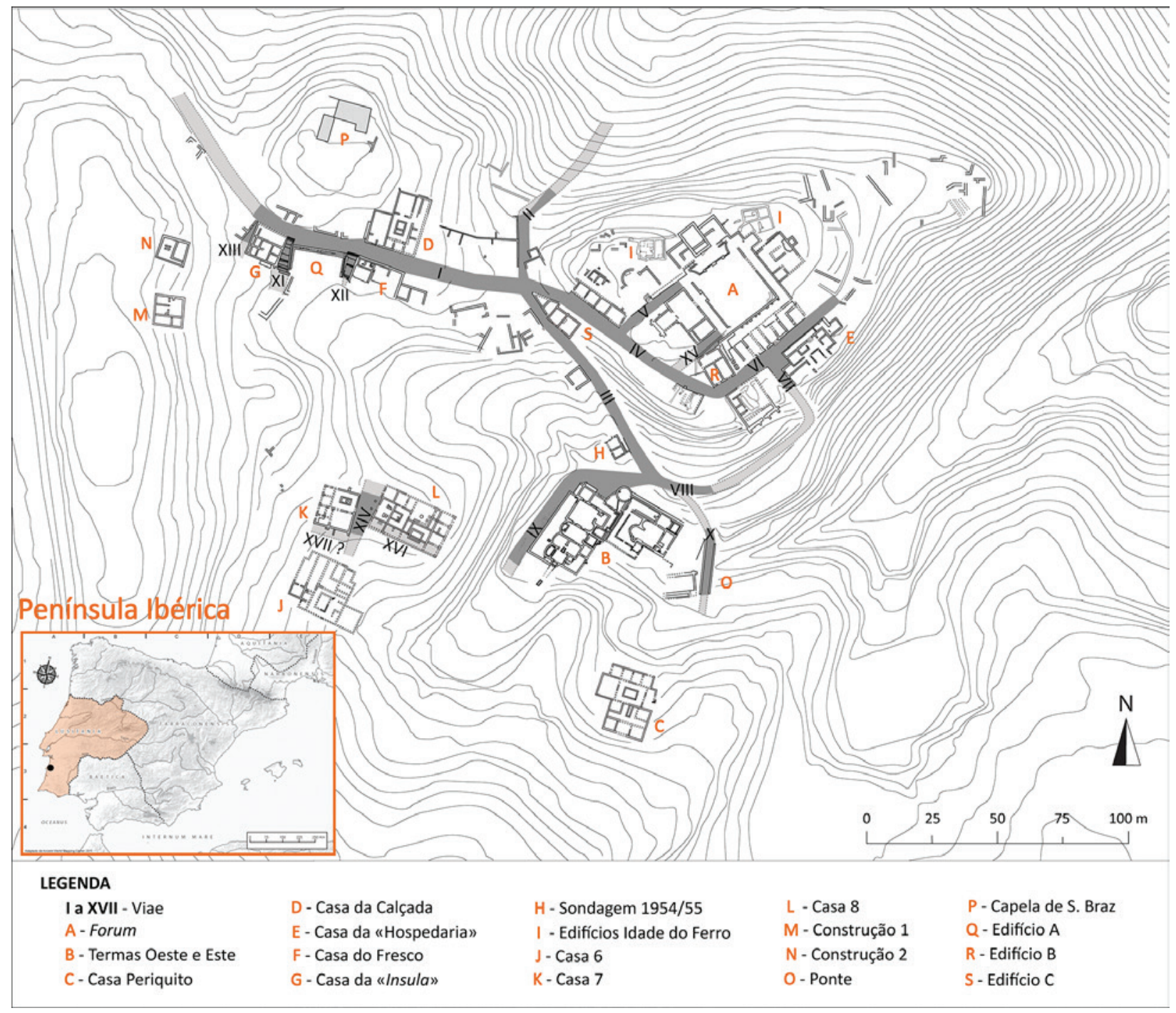

Figura 1 - Planta geral de Mirobriga e localização da Casa da Calçada. 


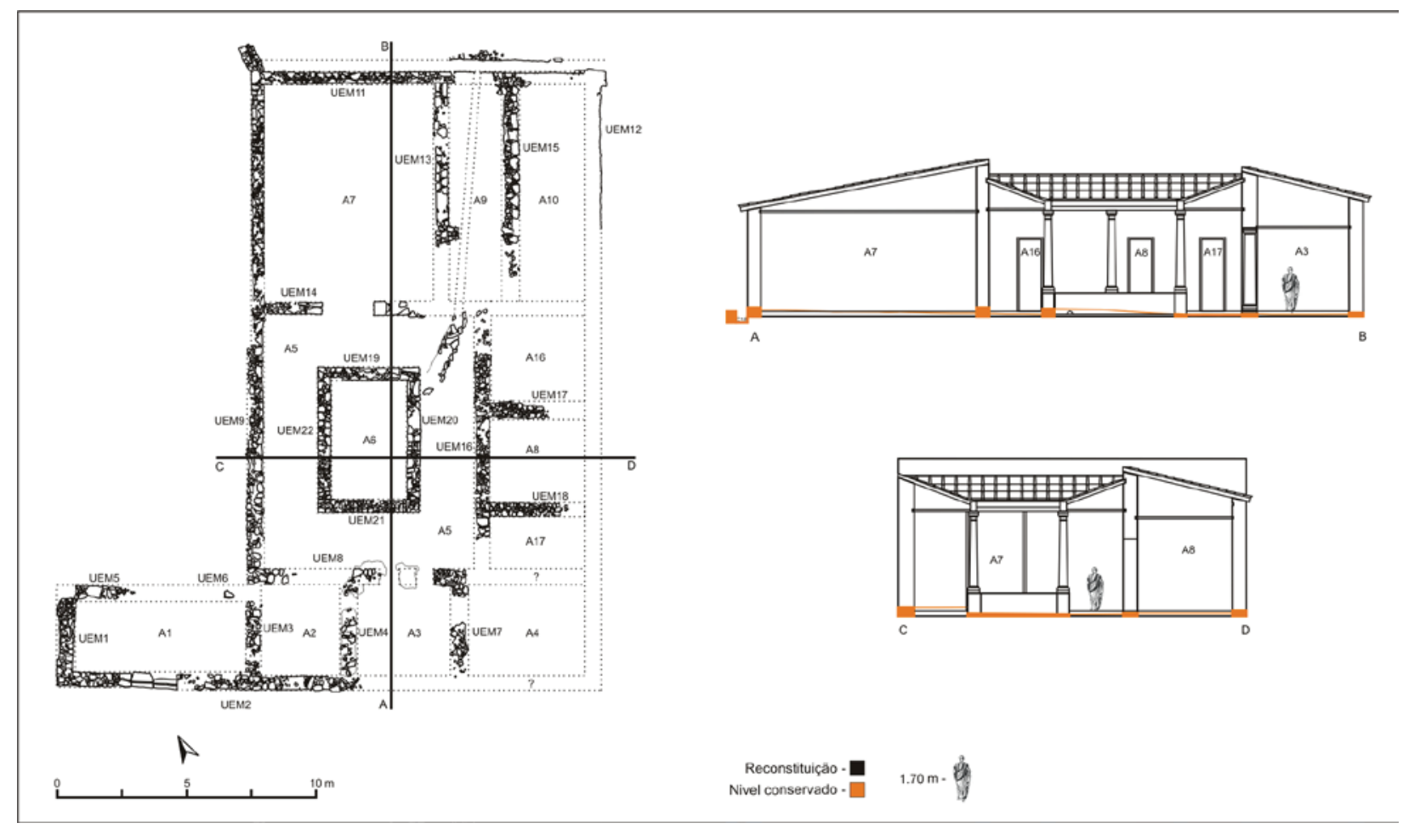

Figura 2 - A: Planimetria da 1ํำ fase; B: Reconstituição em Corte, Norte - Sul (adaptado de Sousa 2018).

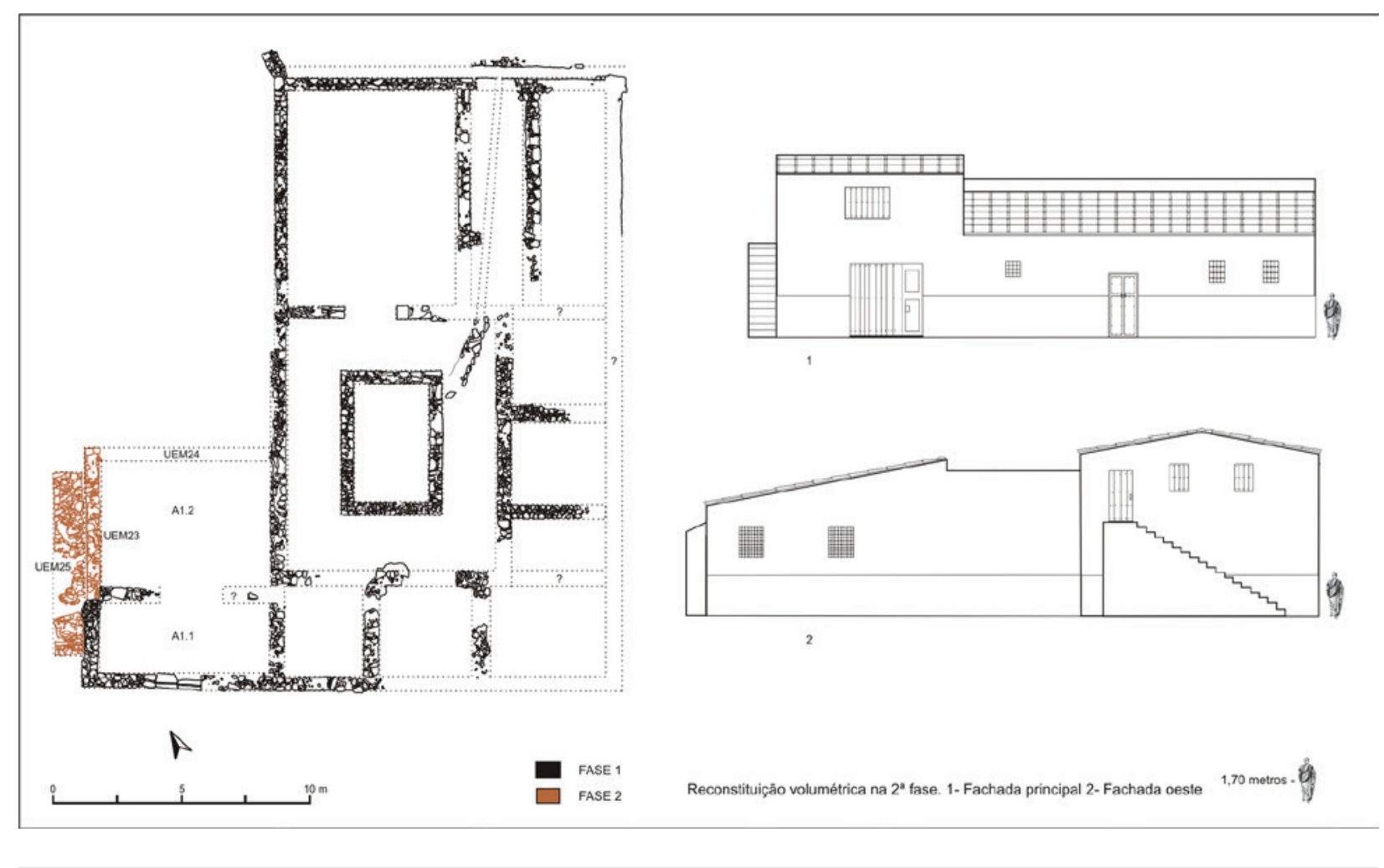

Figura 3 - Planimetria da $2^{\underline{a}}$ fase. Hipótese reconstrutiva das fachadas sul e oeste. 


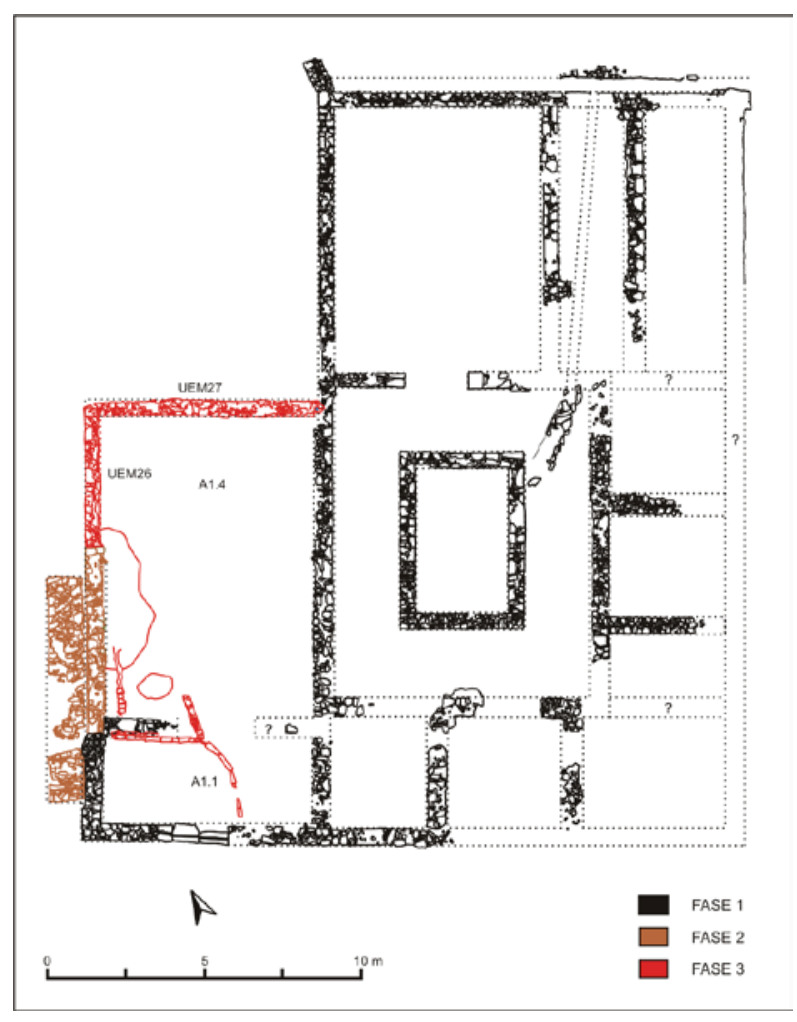

Figura 4 - Planimetria da $3^{\underline{a}}$ fase.

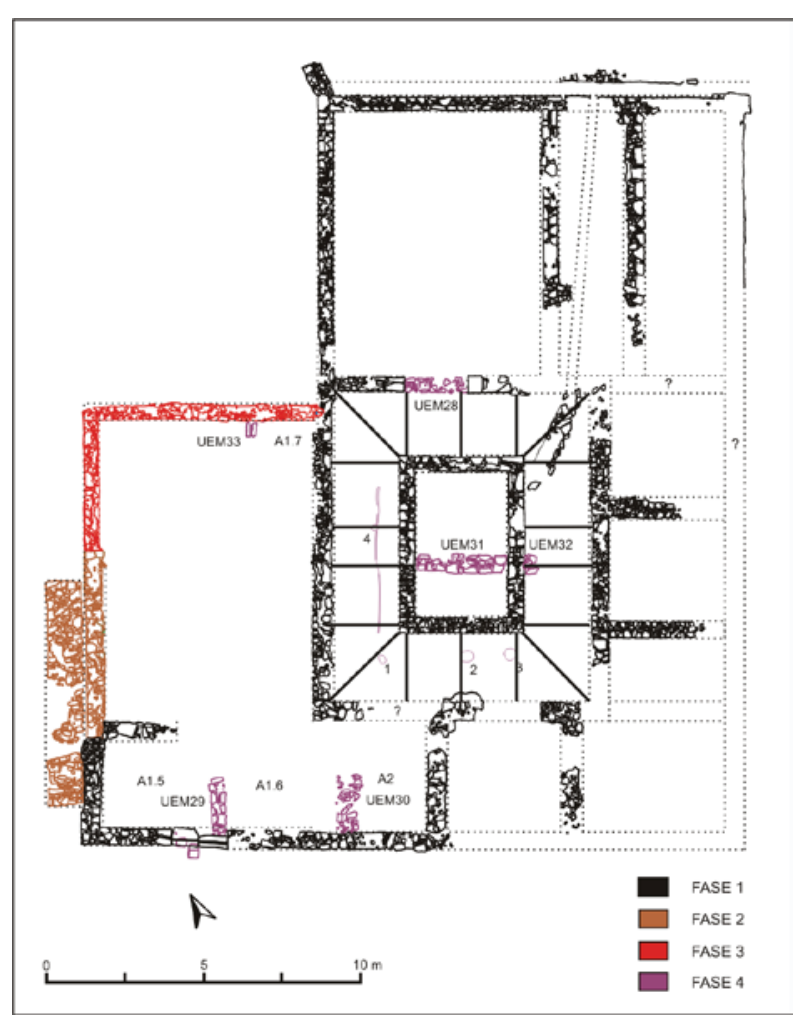

Figura 5 - Planimetria da $4^{\underline{a}}$ fase.

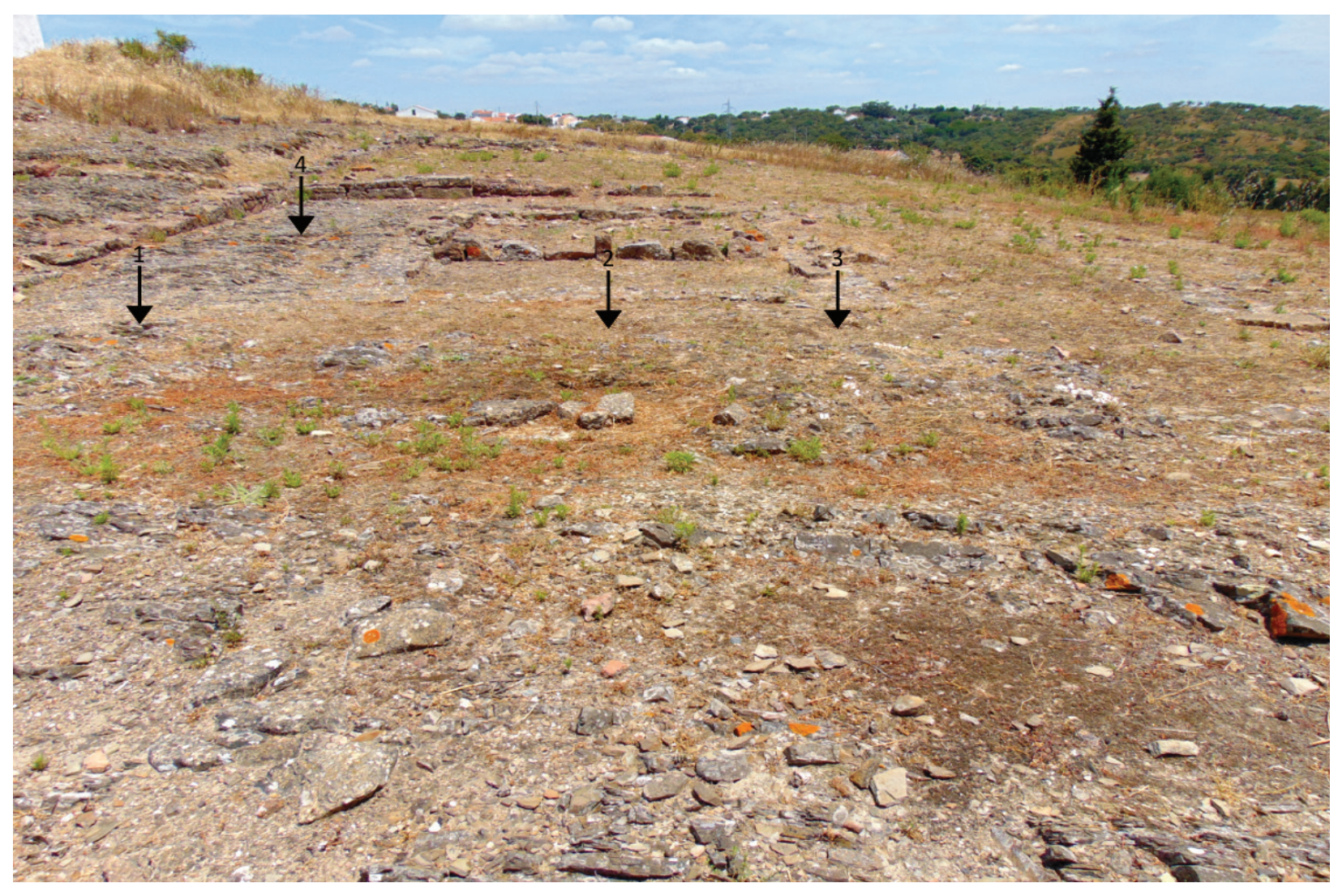

Figura 6 - Área sul da casa, sendo visíveis os buracos de poste e o sulco no ambulatorium este. 


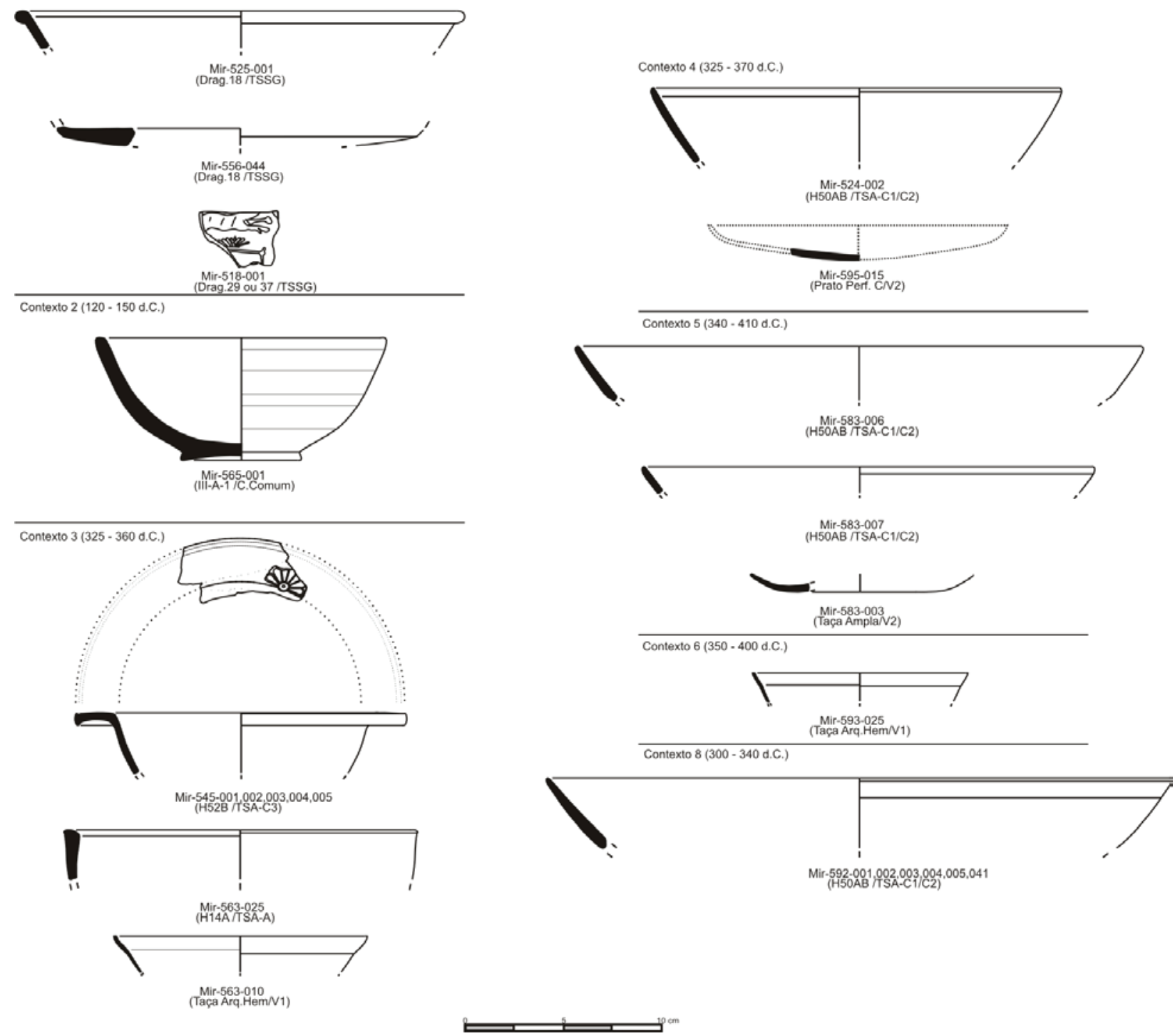

Figura 7 - Materiais datantes dos contextos estratigráficos da Casa da Calçada. 


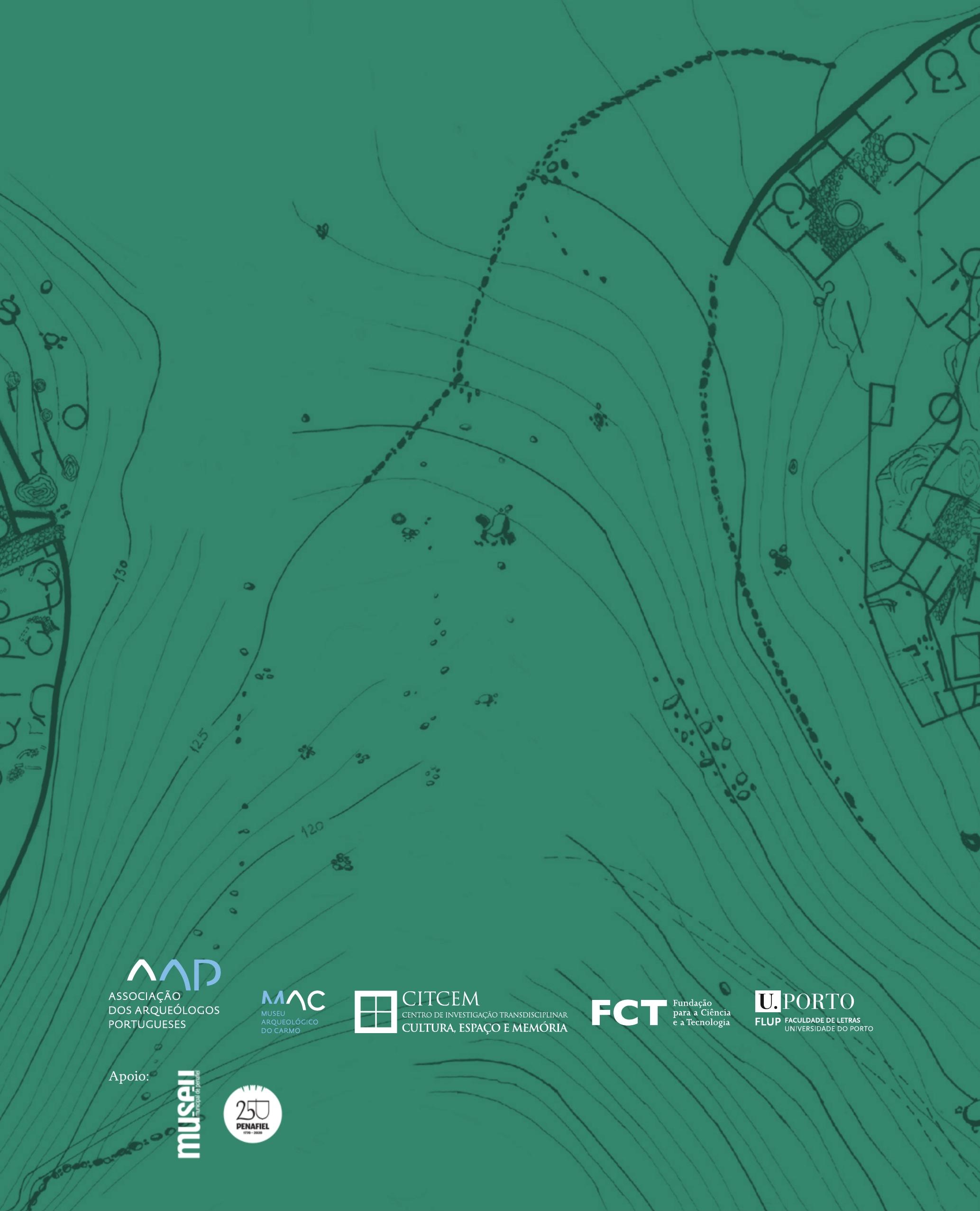

